\title{
AVALIAÇÃO DO POTENCIAL FISIOLÓGICO DE SEMENTES DE TOMATE ATRAVÉS DO TESTE DE TETRAZÓLIO
}

\author{
MAGALI APARECIDA DE OLIVEIRA SANTOS
}

Dissertação apresentada à Escola Superior de Agricultura "Luiz de Queiroz", Universidade de São Paulo, para obtenção do título de Mestre em Agronomia. Área de Concentração: Fitotecnia.

\author{
PIR A C I C A B A \\ Estado de São Paulo - Brasil \\ Março - 2003
}




\section{AVALIAÇÃO DO POTENCIAL FISIOLÓGICO DE SEMENTES DE TOMATE ATRAVÉS DO TESTE DE TETRAZÓLIO}

MAGALI APARECIDA DE OLIVEIRA SANTOS

Engenheira Agrônoma

Orientadora: Dra. ANA DONISIA DA LUZ COELHO NOVEMBRE

Dissertação apresentada à Escola Superior de Agricultura "Luiz de Queiroz", Universidade de São Paulo, para obtenção do título de Mestre em Agronomia. Área de Concentração: Fitotecnia.

PIR A C I C A B A

Estado de São Paulo - Brasil

Março - 2003 


\title{
Dados Internacionais de Catalogação na Publicação (CIP)
} DIVISÃO DE BIBLIOTECA E DOCUMENTAÇ̃̃O - ESALQ/USP

\author{
Santos, Magali A parecida de O liveira \\ A valiação do potencial fisiológico de sementes de tomate através do teste de \\ tetrazólio / M agali A parecida de O liveira Santos. - - Piracicaba, 2003. \\ 68 p. : il. \\ Dissertação (mestrado) - - Escola Superior de A gricultura Luiz de Q ueiroz, 2003. \\ Bibliografia. \\ 1. Fisiologia vegetal 2. Germinação de sementes 3. Teste de tetrazólio 4. Tomate \\ 5. $V$ ariedades vegetais $I$. Título
}

CDD 635.642

\section{"Permitida a cópia total ou parcial deste documento, desde que citada a fonte - O autor"}


Se pensarmos que estamos vencidos, vencidos estamos

Se pensarmos que não atrevemos, não o faremos

Se pensarmos que gostaríamos de ganhar, mas

não podemos...não ganhamos

Isso, porque todo mundo é

aquilo que pensa.

Marco Aurélio (Imperador Romano)

Aos meus pais Silvio e Maria Aparecida, meus irmãos Aguinaldo e Magda, meus cunhados Rosângela e Antônio e meu sobrinho Vitor, pelo amor e exemplo de vida, 


\section{AGRADECIMENTOS}

A Deus, por estar sempre presente em minha vida.

Á Escola Superior de Agricultura "Luiz de Queiroz" - USP/ESALQ, através da Coordenação de Pós-Graduação em Fitotecnia, pela oportunidade de realização do Curso de Mestrado.

À Dra. Ana Dionisia da Luz Coelho Novembre e Dr. Julio Marcos Filho, pela orientação, paciência, apoio e sugestões durante a realização deste trabalho.

Aos Professores Dr. Silvio Moure Cicero e Dr. Walter Rodrigues da Silva, pelos ensinamentos e atenção dispensada durante o curso.

Ao Prof. Dr. Francisco A. Villela (UFPEL), pela amizade e incentivo.

À Engenheira Agrônoma Helena M.C.P. Chamma, pela amizade e colaboração.

À Fundação de Amparo à Pesquisa do Estado de São Paulo (FAPESP), pela concessão da Bolsa de Mestrado.

À Empresa SAKATA, pelo fornecimento das sementes.

À Professora Fernanda Bacelar pela revisão do summary. 
Aos funcionários Ilze H.C.G. das Neves, Hodair L. Banzatto Júnior, Luciane A. Lopes Toledo, Roseneide dos Santos, João E. Jabur Filho e João B. Bigelli, Flávia e Doralice, pelo auxílio durante a realização deste trabalho.

Aos funcionários das Bibliotecas da USP/ESALQ, pelo excelente atendimento.

Aos amigos de todos os Cursos de Pós-Graduação da ESALQ, em especial: Adriana, Alissa, Angélica, Aureny, Carol, Catota, Clodoaldo, Ebert, Ester, Fascina, Heleninha, José Luís, Maria Cristina, Nilza Patrícia, Osmar, Porta, Renata, Roseli, Salvador, Samara, Silvana, Sílva e Suzana, pela amizade incondicional, companheirismo e valiosos momentos compartilhados. 


\section{SUMÁRIO}

Página

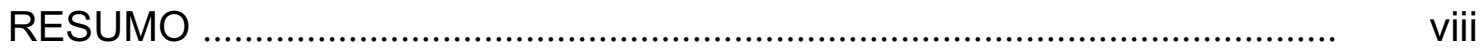

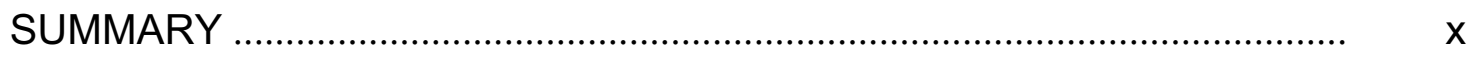

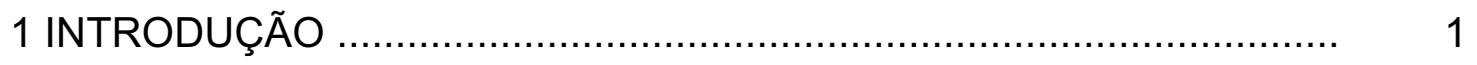

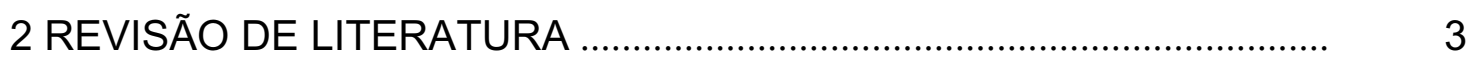

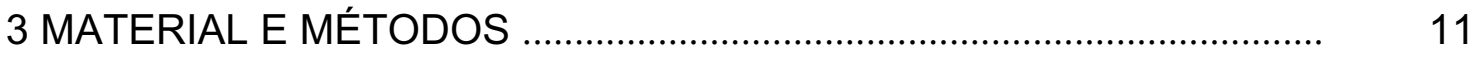

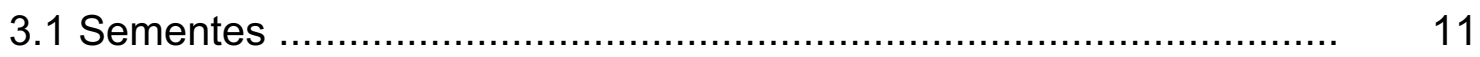

3.2 Fase I - Viabilidade ............................................................. 11

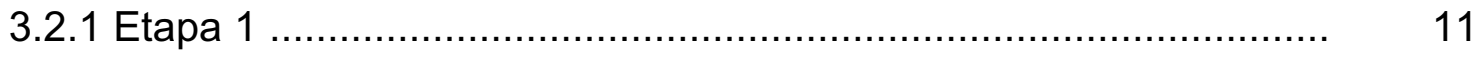

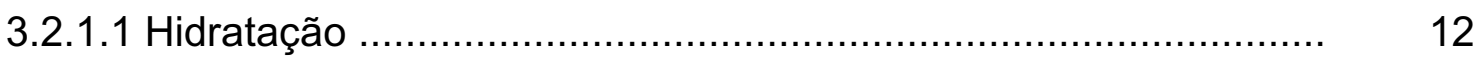

3.2.1.2 Grau de umidade ............................................................... 12

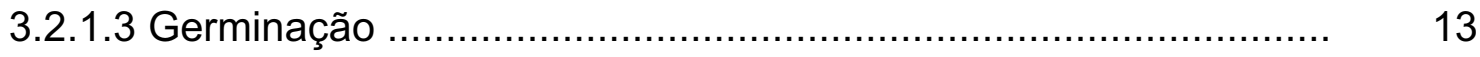

3.2.1.4 Emergência de plântula ........................................................ 13

3.2.1.5 Teste de tetrazólio ................................................................ 14

3.2.1.6 Procedimento estatístico .................................................... 16

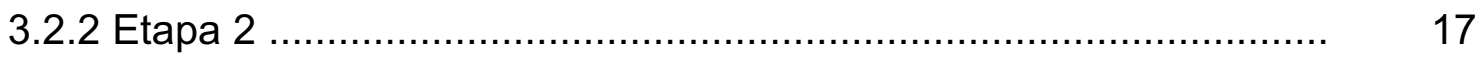

3.2.2.1 Teste de tetrazólio .............................................................. 18

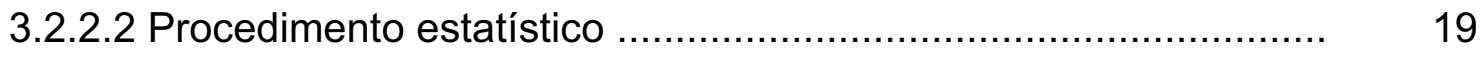

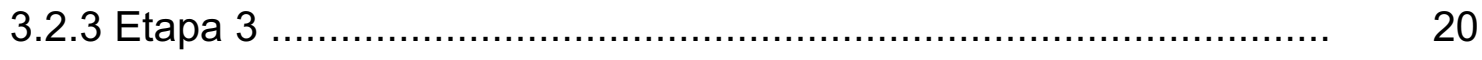

3.2.3.1 Teste de tetrazólio ............................................................. 20

3.2.3.2 Procedimento estatístico …................................................ 21

3.3 Fase II - Viabilidade e Vigor ....................................................... 23

3.3.1 Grau de umidade .................................................................... 23 


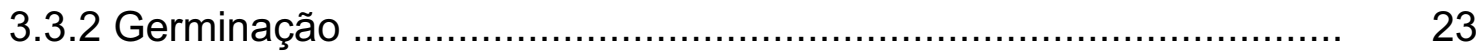

3.3.3 Emergência de plântula ....................................................... 24

3.3.4 Teste de envelhecimento acelerado ...................................... 24

3.3.5 Teste de deterioração controlada ............................................... 24

3.3.6 Teste de tetrazólio ............................................................. 25

3.3.7 Procedimento estatístico ............................................................ 26

4 RESULTADOS E DISCUSSÃO........................................................ 27

4.1 Fase I - Viabilidade.............................................................. 27

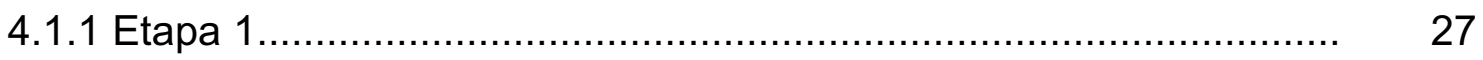

4.1.1.2 Hidratação das sementes.................................................... 27

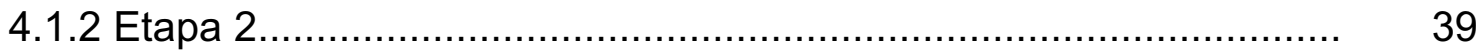

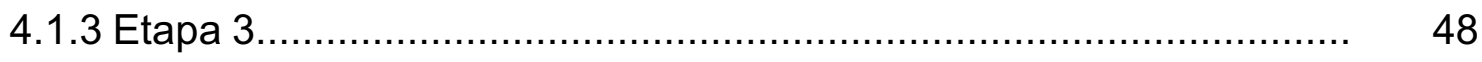

4.2 Fase II - Viabilidade e vigor..................................................... 55

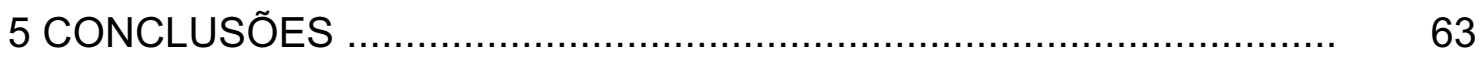

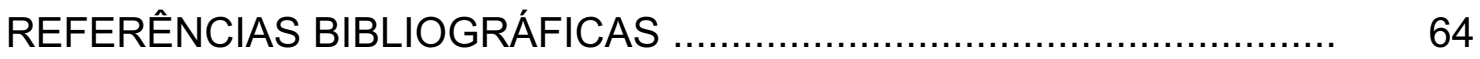




\title{
AVALIAÇÃO DO POTENCIAL FISIOLÓGICO DE SEMENTES DE TOMATE ATRAVÉS DO TESTE DE TETRAZÓLIO
}

\author{
Autora: MAGALI APARECIDA DE OLIVEIRA SANTOS \\ Orientadora: Dra. ANA DIONISIA DA LUZ COELHO NOVEMBRE
}

\section{RESUMO}

A pesquisa teve como objetivo estabelecer uma metodologia específica para a condução do teste de tetrazólio para as sementes de tomate (Lycopersicum lycopersicum L.) com ênfase para o estudo de condições para o preparo e a avaliação das sementes. A pesquisa foi realizada em duas fases: a primeira, utilizando quatro lotes de sementes de tomate do cultivar Bruna, definiu os procedimentos para estimar a viabilidade das sementes; assim, foram testados períodos de hidratação da semente (2, 3 e 4 horas), em duas temperaturas $40^{\circ} \mathrm{C}$ e $45^{\circ} \mathrm{C}$, e de coloração da semente (1, 2 e 3 horas), em solução $0,075 \%$ de $2,3,5$ trifenil cloreto de tetrazólio, a $40^{\circ} \mathrm{C}$. Paralelamente, foi determinado o teor de água das sementes e conduzidos os testes de germinação e de emergência de plântula. Na segunda etapa, utilizando três lotes de sementes de tomate dos cultivares Débora Max e Acclaim, foram estabelecidos os critérios de avaliação das sementes para estimar o vigor. Paralelamente, foram conduzidos os testes de germinação, de emergência de plântula, de envelhecimento acelerado e de deterioração controlada. Os resultados indicaram que a hidratação das sementes por três horas, a $45^{\circ} \mathrm{C}$, associada a três horas de coloração, possibilitou a identificação das estruturas 
vitais da semente e a classificação dos níveis de viabilidade e de vigor. Dessa forma, é possível concluir que o teste de tetrazólio é eficiente para estimar a viabilidade e o vigor de sementes de tomate; há a possibilidade de reduzir o período de tempo para a realização desse teste. 


\title{
TETRAZOLIUM TEST FOR DETERMINING VIABILITY AND VIGOR OF TOMATO SEEDS
}

\author{
Author: MAGALI APARECIDA DE OLIVEIRA SANTOS \\ Adviser: Dra. ANA DIONISIA DA LUZ COELHO NOVEMBRE
}

\section{SUMMARY}

This research was carried out to study procedures for the tetrazolium test to identify viability and vigor of tomato seeds (Lycopersicum lycopersicum L.). In the first experimental stage, using four seed lots from cultivar Bruna, specific studies were carried out to the tetrazolium test for the seed viability evaluation. Then, seed was moistening for two, three and four hours, at $40^{\circ} \mathrm{C}$ or $45^{\circ} \mathrm{C}$, and staining during one, two and three hours, in an aqueous solution $0,075 \%$ of 2,3,5 - triphenyl tetrazolium chloride, at $40^{\circ} \mathrm{C}$. In the second stage, using three lots each from cultivars Debora Max and Acclaim, the tetrazolium test was carried out for the seed vigor evaluation. The late stage also included germination, seedling emergence, accelerated aging and controlled deterioration tests. From the results, the best conditions were three hours moistening, at $45^{\circ} \mathrm{C}$, and staining for three hours. It was concluded that tetrazolium test constitutes an efficient option for the viability an vigor evaluation of tomato seeds; it is possible to reduce the time required for these test execution. 


\section{INTRODUÇÃO}

As hortaliças apresentam importância inegável para a economia nacional e o tomate, pelo crescimento econômico destacado, é uma das mais importantes (Nascimento et al., 1993; Rodo, 1997).

As sementes de tomate, por apresentarem alto valor comercial, merecem maior atenção quanto ao potencial fisiológico (Nascimento et al., 1993). Em vista disso, as empresas têm interesse em técnicas para a produção e o controle da qualidade das sementes comercializadas (Sá, 1999). Como, freqüentemente, as decisões devem ser imediatas, a busca de testes para a análise de sementes, que forneçam resultados rápidos e confiáveis, tem sido incessante.

Por outro lado, existem poucas opções de testes que forneçam respostas relativamente rápidas e o teste de tetrazólio, por suas características, pode ser uma possibilidade. De acordo com Costa et al. (1998) e Vieira \& Von Pinho (1999) a utilização do teste de tetrazólio, para avaliar a qualidade de lotes de

sementes, constitui-se alternativa promissora, sendo adotada em escala crescente no Brasil. Entretanto, conforme destacaram Marcos Filho et al. (1987), o teste ainda não tem uso generalizado, principalmente, devido à falta de treinamento de pessoal e à deficiência de conhecimentos sobre a metodologia adequada para vária espécies.

As informações, disponíveis na literatura, para a realização do teste de tetrazólio de sementes de tomate são restritas e as pesquisas, feitas para outras espécies de hortaliças, têm mostrado a viabilidade de estudos para o aprimoramento desse teste. Dessa forma, essa pesquisa foi desenvolvida com 
o objetivo de estabelecer uma metodologia específica para condução do teste de tetrazólio em sementes de tomate, com ênfase para o estudo de condições para o preparo e a avaliação das sementes. 


\section{REVISÃO DE LITERATURA}

O Brasil produz anualmente cerca de 14 milhões de toneladas de hortaliças (Nascimento, 2001). Dentre as espécies que têm maiores volumes em produção, no ano de 2001, se destaca o tomate com aproximadamente, 3 milhões de toneladas (FNP, 2002). Para atender essa produção, ainda, há a necessidade de importar sementes de diversos países.

As sementes de tomate, por apresentarem alto valor comercial e por serem comercializadas em embalagens impermeáveis, merecem maior atenção quanto ao seu potencial fisiológico (Nascimento et al., 1993). Para tanto, as pesquisas têm sido direcionadas para testes que estimam o vigor das sementes como, por exemplo, os de envelhecimento acelerado (Nascimento et al., 1993, Novembre et al., 1995, Panobianco, 2000), condutividade elétrica (Novembre et al., 1995, Rodo, 1997, Sá, 1999, Panobianco, 2000), deterioração controlada e lixiviação de potássio (Panobianco, 2000).

Durante o processo de produção, as informações sobre o potencial fisiológico das sementes são de importância fundamental para as decisões a serem tomadas. Nesse sentido, o teste de tetrazólio é promissor pois, estima a viabilidade das sementes, fornece informações à respeito do vigor das sementes, a partir de critérios específicos de avaliação e, ainda, indica os principais problemas que podem afetar a qualidade das sementes.

A principal vantagem do teste de tetrazólio é possibilitar a avaliação da viabilidade das sementes em período relativamente curto; os dados obtidos podem ser empregados para o estabelecimento de bases para a comercialização, a determinação do ponto de colheita e a avaliação da 
viabilidade das sementes, durante o processamento e o período de armazenamento (Marcos Filho et al., 1987). Por outro lado, segundo esses autores, algumas limitações têm sido relatadas como: a necessidade de pessoal capacitado, a impossibilidade de identificar a presença de patógenos e de verificar a eficiência de tratamento químico. Entretanto, França Neto et al. (1999) afirmaram que o teste de tetrazólio é altamente eficiente para a identificação de sintomas de ação dos principais fatores que podem comprometer a qualidade da semente de soja.

Esse teste baseia-se na atividade das enzimas desidrogenases que catalisam a reação de redução do sal de tetrazólio (cloreto de 2,3,5 trifenil tetrazólio) nos tecidos vivos. Íons de hidrogênio são transferidos para o sal de tetrazólio que atua como um receptor desse elemento. O tetrazólio que é um sal incolor e difusível é, então, reduzido a um composto não difusível de cor vermelha denominado formazan (Delouche et al., 1962). Como essa reação processa-se no interior das células e o composto formado não se difunde, há a delimitação definida entre o tecido que respira (vivo) e o tecido morto, que não respira (Marcos Filho et al., 1987). Os tecidos deteriorados ou danificados desenvolvem coloração intensa, enquanto que, os vigorosos apresentam coloração suave e os tecidos mortos não desenvolvem coloração, mantendo a cor natural (Delouche et al., 1962).

Para a realização do teste de tetrazólio, é fundamental conhecer a estrutura da semente em análise para poder estabelecer as condições para o preparo e os critérios para avaliação da semente. Geralmente, o início do preparo da semente, para a condução do teste de tetrazólio, é a hidratação.

De acordo com Moore (1977) a hidratação promove o amolecimento da semente, facilitando o preparo da semente e a absorção da solução de tetrazólio, também ativa o sistema enzimático, que resulta em coloração mais nítida. Além disso, esse mesmo autor, afirmou que a absorção de água deve ser lenta para evitar a ocorrência de trincas nas sementes ou a lixiviação de substâncias solúveis, principalmente em sementes deterioradas. Para tanto, 
recomenda a hidratação sobre ou entre folhas de papel, previamente umedecidas, não diretamente em água.

Conforme indicaram Costa et al. (1998) a velocidade de embebição de água aumenta com a elevação da temperatura, promovendo redução do tempo de hidratação e, consequentemente, de execução do teste. Segundo Moore, (1977), as temperaturas mais indicadas durante o período de embebição estão entre $30^{\circ} \mathrm{C}$ e $40^{\circ} \mathrm{C}$. Por outro lado, o teor de água das sementes, após o período de hidratação, é um fator muito importante para o desenvolvimento da coloração no teste de tetrazólio. Nesse sentido, Costa \& Marcos Filho (1994) tiveram resultados satisfatórios para três cultivares de sementes de soja, a partir de $27 \%$ de água. Costa (1992) verificou que esse teor de água pode ser atingido com a hidratação das sementes entre papel, durante 6 horas, a $41^{\circ} \mathrm{C}$. Essas condições permitiram a realização do teste de tetrazólio, em sementes de soja, com redução de 10 horas em relação à metodologia tradicional, 16 horas de hidratação, a $25^{\circ} \mathrm{C}$.

As informações gerais para a realização do teste de tetrazólio, para um grande número de espécies, estão indicadas nas Regras para Análise de Sementes (Brasil, 1992) e têm sido aprimoradas nos últimos anos; assim, os estudos desenvolvidos têm procurado estabelecer a temperatura, a concentração da solução de tetrazólio e a redução do tempo para a realização do teste e os critérios complementares para a avaliação.

Em sementes de cenoura, Andrade et al. (1996) verificaram que o teste de tetrazólio permitiu a caracterização dos embriões das sementes em viáveis e não viáveis, em período de tempo significativamente inferior ao indicado pelas Regras; concluíram que é possível a utilização de 2 horas para a hidratação, a $25^{\circ} \mathrm{C}$, e 1 hora para a coloração, a $35^{\circ} \mathrm{C}$.

Para sementes de abóbora, Dias et al. (2001) concluíram que as condições mais adequadas para a hidratação e o preparo das sementes foram a temperatura de $40^{\circ} \mathrm{C}$ e o período de 1 hora e para a coloração a imersão das sementes em solução de tetrazólio, a $0,075 \%$, por 1 hora, a $40^{\circ} \mathrm{C}$. Dessa forma, 
há possibilidade de classificar as sementes em níveis de viabilidade e de vigor, em período de tempo inferior ao indicado pelas regras.

Existem algumas opções para preparar as sementes para o teste de tetrazólio e a escolha do procedimento depende da espécie (Delouche et al., 1962). Dentre as disponíveis, o corte é uma das mais utilizadas, podendo ser realizado, no sentido longitudinal, transversal ou lateral (Marcos Filho et al., 1987). As sementes de milho, trigo, arroz, capim colonião, brachiaria, entre outras, como as de tomate, devem ser secionadas longitudinalmente considerando a espessura da semente. Esse procedimento é necessário para permitir a exposição do embrião e a absorção da solução de tetrazólio, pois essas sementes têm a cobertura impermeável à solução de tetrazólio.

As sementes, após o preparo, são imersas na solução de tetrazólio durante o período de tempo e em temperatura previamente determinados, conforme a espécie analisada. De acordo com Delouche et al. (1962), as sementes devem permanecer completamente imersas na solução de tetrazólio durante todo o período de coloração. Segundo Marcos Filho et al. (1987), a coloração das sementes em solução de tetrazólio pode ser afetada por vários fatores, como: a temperatura do ambiente, a idade e o nível de deterioração das sementes, o pH e a concentração da solução e o preparo prévio das sementes. Além disso, a coloração das sementes deve ser no escuro, para evitar a alteração da solução de tetrazólio pela ação da luz (Lakon, 1949).

A avaliação das sementes deve ser realizada imediatamente após a coloração porém, para sementes de milho (Dias \& Barros, 1999) e de café (Vieira et al., 1998), existe a possibilidade de manter as sementes imersas em água, sob temperatura de $5^{\circ} \mathrm{C}$, por até 24 horas, sem que ocorra alteração nas estruturas vitais das sementes e, consequentemente, na avaliação. Por outro lado, para sementes de amendoim, Bittencourt \& Vieira (1999) constataram que períodos de tempo maiores que 6 horas, favorecem o desenvolvimento de fungos na superfície interna dos cotilédones e sobre o eixo embrionário, dificultando a análise. Para as sementes de feijão-de-vagem (Bhéring et al., 
1999) e soja (França Neto et al., 1999) a avaliação deve ser feita em, no máximo, 12 horas.

A semente de tomate é formada por uma cobertura protetora, o tecido de reserva, que é constituído pelo endosperma e preenche a maior parte do interior da semente, e pelo embrião, que está inserido no endosperma. O embrião é composto pelo eixo hipocótilo-radícula e pelos dois cotilédones. A parte do eixo acima do nó cotiledonar é constituída pelo epicótilo e contém a plúmula. Sendo assim, para a avaliação do teste de tetrazólio, as estruturas da semente que devem ser observadas são o endosperma, a área de ligação entre os cotilédones e o eixo embrionário, o eixo hipocótilo-radícula e os cotilédones.

De acordo com Grabe (1976), para a avaliação do teste de tetrazólio, deve-se considerar a estrutura da semente, a tonalidade de coloração dos tecidos e, também, devem ser verificadas a turgescência dos tecidos e a ausência de fraturas em regiões vitais da semente. Em geral, os danos que estão próximo ao eixo embrionário, ou o atingem diretamente, são mais prejudiciais que os localizados, por exemplo, nas extremidades dos cotilédones (Vieira \& Von Pinho, 1999).

Para a avaliação da viabilidade e do vigor das sementes de algodão, Vieira \& Von Pinho (1999), recomendaram atenção especial ao eixo hipocótiloradícula e à área de ligação dos cotilédones ao eixo embrionário.

Nas sementes de amendoim, a determinação da viabilidade e do vigor deve ser realizada com base na extensão e na profundidade das injúrias identificadas nos cotilédones (interna e externamente), na plúmula e no eixo hipocótilo-radícula, nesse caso, analisando se o dano atingiu apenas o córtex ou se afetou o cilindro central (Bittencourt \& Vieira, 1999). Em função dos níveis de dano e de deterioração, as sementes são separadas em: viáveis vigorosas apresentam o embrião com coloração rosa suave, sem lesão, ou com lesões superficiais na parte externa ou interna dos cotilédones, sem atingir a região vascular; viáveis não vigorosas - sementes com fratura em um ou ambos os cotilédones, numa extensão inferior à metade da semente, embrião com 
coloração vermelho escuro, apresentando tecidos brilhantes e firmes; e não viáveis: são aquelas que apresentam tecidos mortos, deteriorados ou fraturados na metade superior do eixo hipocótilo-radícula, atingindo o cilindro central, eixo embrionário ou todo o embrião sem coloração ou com coloração amarelo leitoso, com os tecidos flácidos.

Já, em sementes de gramíneas, como as de milho, as áreas vitais consideradas são: a plúmula, o coleoptilo, a região central do escutelo, a radícula e a região situada entre a plúmula e a radícula, onde estão as raízes seminais (Dias \& Barros, 1999). Assim, os critérios estabelecidos por esses mesmos autores para a classificação da viabilidade e do vigor nas sementes de milho, foram: a) sementes viáveis e vigorosas: são as sementes perfeitas, com embrião apresentando coloração rosa brilhante, uniforme e sem lesões ou áreas de coloração mais intensa ou não colorida, que indicam pontos deteriorados ou tecidos mortos; b) sementes viáveis não vigorosas: apresentam o embrião com coloração vermelha intensa, indicando tecidos deteriorados, ou com danos atingindo a radícula, sem afetar a região das raízes seminais. As que possuem danos em áreas maiores do escutelo, desde que não atinjam a região central, o que indica capacidade para produzir uma plântula normal; c) sementes não viáveis: são as que apresentam o embrião colorido, mas devido a danos críticos ou ausência de coloração nas áreas vitais, são incapazes de originar plântulas normais. O endosperma de sementes das gramíneas não é considerado como área vital, por ser constituído de tecido morto (Delouche et al., 1962). No entanto, Moore (1977) citou que o endosperma é vivo nas sementes maduras de Liliiaceae, Umbelliferae, Rubiaceae e Solanaceae.

Para as sementes de soja, França Neto et al. (1999) citaram os cuidados especiais que deverão ser considerados durante a avaliação do eixo hipocótiloradícula pois, o cilindro central é a estrutura mais crítica dessa região e se for atingido por algum dano, a semente não será considerada viável. Outra região crítica na semente de soja é a região vascular, se for afetada a viabilidade e/ou o vigor da semente poderão ser comprometidos. Além da integridade dessas 
estruturas, foram estabelecidos critérios de avaliação com base na coloração dos tecidos, assim, vermelho carmim: tecido vivo e vigoroso; vermelho carmim forte: tecido em deterioração e branco leitoso: tecido morto.

Segundo Delouche et al. (1962) tecidos vigorosos, geralmente túrgidos, vão se colorindo de forma lenta e uniforme. A ocorrência da coloração vermelha intensa é característica de tecidos em deterioração, que permitem maior difusão da solução de tetrazólio, através de membranas celulares já comprometidas. A ausência de coloração identifica tecidos mortos, que não apresentam atividade enzimática suficiente para a produção do formazan. Esses tecidos, normalmente, são flácidos e apresentam cor branca opaca mas, podem ser amarelados, cinzentos ou esverdeados, principalmente quando existem danos causados por insetos. Por outro lado, nas condições estipuladas para a realização do teste, em sementes de algodão, Vieira \& Von Pinho (1999) observaram que os tecidos de sementes vigorosas restringem a entrada rápida da solução de tetrazólio, a coloração é rosa claro ou, até mesmo, não há a coloração dos tecidos mais internos. Os tecidos são firmes, túrgidos e brilhantes, indicando que a ausência de coloração ou a coloração rosa suave é consequência da resistência do sistema de membranas à entrada da solução de tetrazólio.

Entretanto, como todo teste, o de tetrazólio também apresenta limitações e alguns cuidados devem ser tomados no sentido de serem obtidos resultados mais precisos (Bittencourt, 1999). A obtenção de resultados precisos e reproduzíveis exige, principalmente, conhecimento específico da estrutura da semente e de todas as técnicas e dos procedimentos envolvidos no teste (França Neto et al., 1999). Segundo esses autores, a análise de sementes pelo teste de tetrazólio em nosso País não se destaca apenas em relação aos aspectos quantitativos mas, principalmente, aos qualitativos pois, quando realizado em conjunto com outros testes, tem propiciado a comercialização de lotes de alta qualidade. 
Os dados da literatura indicaram que as pesquisas com o teste de tetrazólio têm trazido resultados positivos e que há possibilidade de aprimoramento do método para as sementes de outras espécies. 


\section{MATERIAL E MÉTODOS}

A pesquisa foi conduzida, em duas fases, no período de outubro de 2000 a junho de 2002, nos Laboratórios de Análise de Sementes e de Análise de Imagem, do Departamento de Produção Vegetal da Escola Superior de Agricultura "Luiz de Queiroz", da Universidade de São Paulo, Piracicaba - SP.

Os testes realizados foram repetidos três vezes, com intervalos de, aproximadamente 15 dias, para estabelecer a comparação entre os resultados.

\subsection{Sementes}

Foram utilizadas sementes de tomate (Lycopersicum lycopersicum L.), dos cultivares Bruna (safras 1996/97) e Débora Max (safra 2001), do grupo Santa Cruz, e Acclaim (safra 2000), do grupo Salada.

No início do experimento, os lotes foram homogeneizados e divididos, utilizando divisor de solo, para obtenção das repetições estatísticas.

Durante o período experimental, as sementes permaneceram embaladas em sacos de papel e armazenadas em câmara regulada a $20^{\circ} \mathrm{C}$ e $55 \%$ de umidade relativa do ar.

\subsection{Fase I - Viabilidade}

\subsubsection{Etapa 1}


Nessa etapa, para estimar a viabilidade das sementes pelo teste de tetrazólio, foram estudados os procedimentos para o preparo e a avaliação das sementes de tomate. Foram utilizados quatro lotes de sementes, do cultivar Bruna, para as seguintes determinações: hidratação da semente, grau de umidade, germinação, emergência de plântula e tetrazólio.

\subsubsection{Hidratação da semente}

A absorção de água pelas sementes de tomate foi avaliada, para estabelecer o procedimento mais adequado para a condução do teste de tetrazólio. Para tanto, primeiramente foi determinado o grau de umidade das sementes pelo método da estufa a $105 \pm 3^{\circ} \mathrm{C}$, por 24 horas (Brasil, 1992), com os resultados expressos em porcentagem (base úmida). A seguir, foram obtidas quatro repetições com, aproximadamente, $1 \mathrm{~g}$ de sementes por lote, para estabelecer o ganho de água pela imersão direta em água e pela absorção de água do papel toalha. Para a hidratação em água, as sementes foram imersas em $40 \mathrm{~mL}$ de água. Para a hidratação entre papel, as sementes foram distribuídas entre duas folhas de papel toalha $(10,5 \times 10,5 \mathrm{~cm})$, previamente umedecidas (2,5 vezes o peso do substrato seco), e, posteriormente, mantidas no interior de caixas plásticas transparentes $(11 \times 11 \times 3 \mathrm{~cm})$. Em seguida, as sementes submetidas aos dois sistemas de hidratação foram colocadas em germinador a $40^{\circ} \mathrm{C}$ e a $45^{\circ} \mathrm{C}$. As amostras foram pesadas a cada hora, durante 5 horas. O grau de umidade das sementes, correspondente a cada período de hidratação, foi calculado a partir do teor de água inicial e os resultados foram indicados em porcentagem (base úmida) para cada lote.

\subsubsection{Grau de umidade}

A determinação do grau de umidade foi realizada pelo método da estufa a $105 \pm 3^{\circ} \mathrm{C}$, por 24 horas, conforme as Regras para Análise de Sementes - RAS 
(Brasil, 1992). As médias dos resultados foram expressas em porcentagem (base úmida) para cada lote.

\subsubsection{Germinação}

O teste de germinação foi realizado utilizando quatro repetições de 50 sementes para cada lote. As sementes foram distribuídas sobre duas folhas de papel mata borrão $(10,5 \times 10,5 \mathrm{~cm})$, colocadas no interior de caixas plásticas transparentes $(11 \times 11 \times 3 \mathrm{~cm})$, previamente umedecidas com quantidade de água correspondente a 2,5 vezes o peso do substrato seco, a $20-30^{\circ} \mathrm{C}$, em presença de luz durante oito horas, em cada 24 horas. As avaliações foram efetuadas aos 7 e aos 14 dias após a semeadura e as médias dos resultados, considerando as plântulas normais, expressas em porcentagem (Brasil, 1992).

\subsubsection{Emergência de plântula}

Para a condução do teste, foram utilizadas quatro repetições de 50 sementes por lote, semeadas individualmente em bandejas de poliestireno (isopor) com 200 células, contendo substrato comercial (Plantimax Hortaliças). Após a semeadura, as sementes foram cobertas por uma camada de vermiculita expandida (Rodo, 2002) e o substrato umedecido com, aproximadamente, $380 \mathrm{~mL}$ de água por bandeja. As bandejas foram mantidas em condições ambientais não controladas de laboratório. Durante todo o período do teste o substrato foi reumedecido diariamente. Para a avaliação das plântulas de tomate foi utilizado o Método Agroflora, adaptado de Panobianco (2000), e os critérios considerados foram: 1) plântula normal: os dois cotilédones íntegros, completamente expandidos, ambos fixos e verdes; o hipocótilo ereto, curto, sem fendas (rachaduras) ou lesões; o epicótilo presente, com a primeira folha verdadeira expandida e a raiz presente, mas não visível; foram, também, consideradas as plântulas com três folhas cotiledonares; 2) 
plântula normal fraca: com, no mínimo, um cotilédone ou ambos, mas não expandidos totalmente, presos pelo tegumento, verdes, com menos de $50 \%$ da área danificada; o hipocótilo ereto, curto ou levemente alongado, sem fendas ou lesões; o epicótilo presente, com a primeira folha verdadeira visível mas, ainda, não desenvolvida e a raiz presente, mas não visível; 3) plântula anormal: cotilédones ausentes ("cotilédone cego") ou quando presentes, brancos ou amarelados, com mais de $50 \%$ da superfície cotiledonar danificada; o hipocótilo encurvado, fendido, estiolado ou com aparência transparente; sem epicótilo e a raiz ausente ou presente acima da superfície do substrato. A avaliação foi realizada aos 14 dias após a semeadura, através da contagem das plântulas emersas normais e fracas, com as médias dos resultados expressas em porcentagem.

\subsubsection{Teste de tetrazólio}

Para esse teste, foram utilizadas três repetições de 20 sementes, para cada lote, hidratadas entre $1 / 2$ folha papel tolha $(19 \times 30 \mathrm{~cm})$, previamente umedecida com quantidade de água correspondente a 2,5 vezes o peso do papel seco, durante 2,3 e 4 horas, a $40^{\circ} \mathrm{C}$ ou $45^{\circ} \mathrm{C}$. As sementes hidratadas foram cortadas longitudinalmente, dividindo a semente bilateralmente pela espessura, mas sem separar as duas metades. A seguir, as sementes cortadas foram imersas em, aproximadamente, $15 \mathrm{~mL}$ de solução de 2,3,5 trifenil cloreto de tetrazólio $0,075 \%$, a $40^{\circ} \mathrm{C}$, pelos períodos de 1,2 e 3 horas, no interior de uma estufa, conforme os tratamentos da Tabela 1. 
Tabela 1. Períodos de hidratação, a $40^{\circ} \mathrm{C}$ e a $45^{\circ} \mathrm{C}$, e de coloração, a $40^{\circ} \mathrm{C}$, em solução de tetrazólio a $0,075 \%$, para 4 lotes de sementes de tomate, cv. Bruna (Etapa1).

\begin{tabular}{cc}
\hline Tratamento & $\begin{array}{c}\text { Período (hora) } \\
\text { Hidratação/Coloração }\end{array}$ \\
\hline T1 & $2 / 1$ \\
T2 & $2 / 2$ \\
T3 & $2 / 3$ \\
T4 & $3 / 1$ \\
T5 & $3 / 2$ \\
T6 & $3 / 3$ \\
T7 & $4 / 1$ \\
T8 & $4 / 2$ \\
T9 & $4 / 3$ \\
\hline
\end{tabular}

Decorridos os períodos para a coloração, a solução de tetrazólio foi drenada, as sementes lavadas em água corrente e, em seguida, mantidas imersas em água até o momento da avaliação. As sementes foram examinadas individualmente em microscópio estereoscópico, com aumento de 40 vezes, e a avaliação feita considerando apenas uma das metades. A classificação da viabilidade das sementes, em duas categorias, foi feita com base nos critérios propostos por Bittencourt \& Vieira (1999) e Dias \& Barros (1999): 1) viáveis: coloração rosa claro em toda a extensão do embrião e do endosperma, com tecidos firmes e túrgidos, sem apresentar lesões visíveis, ou com tecidos firmes e túrgidos não coloridos em menos de $50 \%$ das áreas dos cotilédones ou do endosperma, a extremidade do eixo hipocótilo-radícula pode estar sem coloração. São sementes que indicam a possibilidade de originarem plântulas normais; 2) não viáveis: são aquelas com mais de $50 \%$ das áreas dos cotilédones e/ou do endosperma não coloridas, ou com ausência de coloração na região da extremidade da radícula, com tecidos flácidos e brancos ou amarelados, sem lesões visíveis; podem ter, também, áreas do endosperma 
e/ou do embrião totalmente sem coloração. Essas sementes indicam a possibilidade de originarem plântulas anormais ou apresentam estado metabólico característico de sementes mortas.

Após a avaliação das sementes pelo teste de tetrazólio, foram tiradas fotografias das sementes viáveis e não viáveis, utilizando a câmera digital, marca Nikon, modelo D1. A seguir, as imagens foram transferidas para o computador, pelo programa Nikoncapture - Powerful Imaging Software for the Nikon D1 e ajustadas utilizando o programa Photoshop 6.

\subsubsection{Procedimento estatístico}

A análise dos dados do teste de tetrazólio foi realizada utilizando o delineamento experimental inteiramente casualizado, em arranjo fatorial (4 lotes x 9 tratamentos), com três repetições, segundo o esquema de análise de variância apresentado na Tabela 2. Para os resultados de germinação e emergência de plântula foi utilizado o delineamento inteiramente casualizado, com quatro repetições, segundo o esquema de análise de variância apresentado na Tabela 3. Os dados dos testes de tetrazólio, germinação e emergência de plântula foram transformados em arc sen $\sqrt{x / 100}$. A comparação de médias foi efetuada pelo teste de Tukey $(p<0,05)$. Não foi realizada análise estatística dos dados obtidos para os graus de umidade das sementes. Para execução da análise estatística foi utilizado o Sistema de Análise Estatística para Microcomputadores - SANEST (Zonta \& Machado, 1984). 
Tabela 2. Esquema de análise de variância para o teste de tetrazólio (Etapa 1).

\begin{tabular}{lc}
\hline Causa de variação & Grau de liberdade \\
\hline Lotes & 3 \\
Tratamentos & 8 \\
Lotes x Tratamentos & 24 \\
Resíduo & 72 \\
$\quad$ Total & 107 \\
\hline
\end{tabular}

Tabela 3. Esquema de análise de variância para os testes de germinação e de emergência de plântula (Etapa 1).

\begin{tabular}{|c|c|}
\hline Causa de variação & Grau de liberdade \\
\hline Lotes & 3 \\
\hline Resíduo & 12 \\
\hline Total & 15 \\
\hline
\end{tabular}

\subsubsection{Etapa 2}

A partir dos resultados obtidos na primeira etapa, foram selecionados os tratamentos considerados mais adequados (3/1, 3/2 e 3/3) para a avaliação da viabilidade das sementes pelo teste de tetrazólio. Foram utilizados quatro lotes de sementes, do cultivar Bruna e os testes conduzidos seguiram os mesmos procedimentos descritos na etapa 1: grau de umidade (item 3.2.1.2), germinação (item 3.2.1.3), emergência de plântula (item 3.2.1.4). O teste de tetrazólio foi realizado conforme descrito a seguir. 


\subsubsection{Teste de tetrazólio}

Para essa avaliação, foram utilizadas três repetições de 20 sementes para cada lote, hidratadas entre $1 / 2$ folha papel tolha $(19 \times 30 \mathrm{~cm})$, previamente umedecida com volume de água correspondente a 2,5 vezes o peso do papel seco, durante 3 horas, a $40^{\circ} \mathrm{C}$ ou $45^{\circ} \mathrm{C}$. As sementes hidratadas foram cortadas longitudinalmente, dividindo a semente bilateralmente pela espessura, mas sem separar as duas metades. A seguir, as sementes cortadas foram imersas em, aproximadamente, $15 \mathrm{~mL}$ de solução de tetrazólio $0,075 \%$, a $40^{\circ} \mathrm{C}$ pelos períodos de 1, 2 e 3 horas, no interior de uma estufa. O período de 3 horas de hidratação em combinação com os períodos de 1, 2 e 3 horas de coloração estão representados pelos tratamentos T4, T5 e T6, da Tabela 4.

Tabela 4. Períodos de hidratação, a $40^{\circ} \mathrm{C}$ e $45^{\circ} \mathrm{C}$, e de coloração, a $40^{\circ} \mathrm{C}$, em solução de tetrazólio a $0,075 \%$, para 4 lotes de sementes de tomate, cv. Bruna (Etapa2).

\begin{tabular}{cc}
\hline Tratamento & $\begin{array}{c}\text { Período (hora) } \\
\text { Hidratação/Coloração }\end{array}$ \\
\hline T4 & $3 / 1$ \\
T5 & $3 / 2$ \\
T6 & $3 / 3$ \\
\hline
\end{tabular}

Decorridos os períodos para a coloração, a solução de tetrazólio foi drenada, as sementes lavadas em água corrente e, em seguida, mantidas imersas em água até o momento da avaliação. Os critérios considerados para a classificação das sementes em viáveis e não viáveis e os procedimentos para registrar as imagens fotográficas dessas sementes foram os mesmos descritos no item 3.2.1.5. 


\subsubsection{Procedimento estatístico}

A análise dos dados do teste de tetrazólio foi realizada utilizando o delineamento experimental inteiramente casualizado, em arranjo fatorial (4 lotes x 3 tratamentos), com três repetições, segundo o esquema de análise de variância apresentado na Tabela 5. Para os resultados de germinação e emergência de plântula foi utilizado o delineamento inteiramente casualizado, com quatro repetições, segundo o esquema de análise de variância apresentado na Tabela 6 . Os dados dos testes de tetrazólio, germinação e emergência de plântula foram transformados em arc sen $\sqrt{x / 100}$. A comparação de médias foi efetuada pelo teste de Tukey $(p<0,05)$. Não foi realizada análise estatística dos dados obtidos para os graus de umidade das sementes. Para execução da análise estatística foi utilizado o Sistema de Análise Estatística para Microcomputadores - SANEST (Zonta \& Machado, 1984).

Tabela 5. Esquema de análise de variância para o teste de tetrazólio (Etapa 2).

\begin{tabular}{lc}
\hline Causa de variação & Grau de liberdade \\
\hline Lotes & 3 \\
Tratamentos & 2 \\
Lotes x Tratamentos & 6 \\
Resíduo & 24 \\
$\quad$ Total & 35 \\
\hline
\end{tabular}


Tabela 6. Esquema de análise de variância para os testes de germinação e de emergência de plântula (Etapa 2).

\begin{tabular}{|c|c|}
\hline Causa de variação & Grau de liberdade \\
\hline Lotes & 3 \\
\hline Resíduo & 12 \\
\hline Total & 15 \\
\hline
\end{tabular}

\subsubsection{Etapa 3}

Nessa etapa da pesquisa, os dados foram coletados para comparar o tratamento definido nas etapas 1 e 2, com a indicação das Regras para Análise de Sementes (Brasil, 1992), para o teste de tetrazólio em sementes de tomate, utilizando os quatro lotes do cultivar Bruna. Os testes conduzidos nessa etapa seguiram os mesmos procedimentos descritos na etapa 1: grau de umidade (item 3.2.1.2), germinação (item 3.2.1.3), emergência de plântula (item 3.2.1.4). O teste de tetrazólio foi realizado conforme descrito a seguir.

\subsubsection{Teste de tetrazólio}

Foram utilizadas quatro repetições de 25 sementes para cada lote, hidratadas entre $1 / 2$ folha papel tolha $(19 \times 30 \mathrm{~cm})$, previamente umedecida com volume de água correspondente a 2,5 vezes o peso do papel seco, durante 3 horas, a $45^{\circ} \mathrm{C}$. As sementes hidratadas foram cortadas longitudinalmente, dividindo a semente bilateralmente pela espessura, mas sem separar as duas metades. A seguir, as sementes cortadas foram imersas em, aproximadamente, $15 \mathrm{~mL}$ de solução de tetrazólio $0,075 \%$, a $40^{\circ} \mathrm{C}$ durante 3 horas, no interior de uma estufa.

Decorrido o período para a coloração, a solução de tetrazólio foi drenada, as sementes lavadas em água corrente e, em seguida, mantidas imersas em 
água até o momento da avaliação. A avaliação das sementes viáveis e não viáveis foi realizada da mesma forma descrita no item 3.2.1.5.

Utilizando os procedimentos indicados nas Regras para Análise de Sementes (Brasil, 1992), foram testadas quatro repetições de 25 sementes para cada lote, hidratadas entre duas folhas de papel toalha $(10,5 \times 10,5 \mathrm{~cm})$ durante 18 horas, a $30^{\circ} \mathrm{C}$. Após a hidratação, foi feito o corte longitudinal, de modo a dividir a semente bilateralmente pela espessura, mas sem separar as duas metades; a seguir, as sementes cortadas foram imersas em solução de tetrazólio $0,5 \%$, a $30^{\circ} \mathrm{C}$ durante $3,4,5$ e 6 horas, no interior de uma estufa. Após esses períodos, a solução foi drenada, as sementes foram lavadas em água corrente e, em seguida, mantidas imersas em água até o momento da avaliação. Para a avaliação, as sementes foram classificadas em duas categorias, com base nas indicações propostas pelas Regras para Análise de Sementes: 1) viáveis: embrião e endosperma completamente coloridos, que possibilitem originar plântulas normais; 2) não viáveis: áreas vitais com tecidos não coloridos, flácidos ou necrosados, indicando estado metabólico característico de sementes mortas. Nesse critério de avaliação não há indicação referentes à plântula anormal.

Para os dois métodos utilizados, as sementes foram examinadas individualmente em microscópio estereoscópico, com aumento de 40 vezes, considerando apenas uma das metades, e os resultados expressos em porcentagem de sementes viáveis.

Após a avaliação das sementes de tomate pelo teste de tetrazólio, pelas duas metodologias, foram tiradas fotografias das sementes viáveis e não viáveis, conforme indicado no item 3.2.1.5.

\subsubsection{Procedimento estatístico}

A análise dos dados do teste de tetrazólio foi realizada utilizando o delineamento experimental inteiramente casualizado, em arranjo fatorial (4 lotes 
x 4 tratamentos), com quatro repetições, segundo esquema de análise de variância apresentado na Tabela 7. Para os resultados de germinação, emergência de plântula e tetrazólio, no método indicado pela pesquisa, também foi utilizado o delineamento inteiramente casualizado, com quatro repetições, conforme o esquema de análise de variância apresentado na Tabela 8. Os dados dos testes de tetrazólio, germinação e emergência de plântula foram transformados em arc sen $\sqrt{x / 100}$. A comparação de médias foi efetuada pelo teste de Tukey $(p<0,05)$. Não foi realizada análise estatística dos dados obtidos para os graus de umidade das sementes. Para execução da análise estatística foi utilizado o Sistema de Análise Estatística para Microcomputadores SANEST (Zonta \& Machado, 1984).

Tabela 7. Esquema de análise de variância para o teste de tetrazólio, método das Regras para Análise de Sementes. (Etapa 3).

\begin{tabular}{lc}
\hline Causa de variação & Grau de liberdade \\
\hline Lote & 3 \\
Tratamentos & 3 \\
Lotes x Tratamentos & 9 \\
Resíduo & 48 \\
$\quad$ Total & 63 \\
\hline
\end{tabular}


Tabela 8. Esquema de análise de variância para os testes de germinação, emergência de plântula e tetrazólio (Etapa 3).

\begin{tabular}{lc}
\hline Causa de variação & Grau de liberdade \\
\hline Lotes & 3 \\
Resíduo & 12 \\
\multicolumn{1}{c}{ Total } & 15 \\
\hline
\end{tabular}

\subsection{Fase II - Viabilidade e Vigor}

Análises complementares foram realizadas nessa fase, para tentar identificar alterações nos tecidos das sementes viáveis, pelo teste de tetrazólio, que possibilitassem a classificação das sementes quanto ao vigor. Foram utilizados dois novos cultivares Débora Max e Acclaim, também, para verificar novamente a eficiência do método proposto pela pesquisa. Os testes realizados para cada cultivar foram: determinação do grau de umidade, germinação, emergência de plântula, tetrazólio, envelhecimento acelerado e deterioração controlada.

\subsubsection{Grau de umidade}

Foi utilizado o método indicado no item 3.2.1.2.

\subsubsection{Germinação}

Foi utilizado o método indicado no item 3.2.1.3. 


\subsubsection{Emergência de plântula}

Para condução desse teste, foi utilizado o mesmo procedimento descrito no item 3.2.1.4. As avaliações da germinação das sementes e do vigor das plântulas de tomate, foram realizadas aos 14 dias após a semeadura; para a germinação foram consideradas as plântulas normais e normais fracas e para o vigor somente as normais (Panobianco, 2000). As médias dos resultados foram expressas em porcentagem.

\subsubsection{Teste de envelhecimento acelerado}

Nesse teste, foram utilizadas caixas plásticas $(11 \times 11 \times 3 \mathrm{~cm})$ como compartimentos individuais (mini-câmara), possuindo em seu interior uma bandeja com tela, sobre a qual foram distribuídas $3 \mathrm{~g}$ de sementes. No fundo de cada caixa, foram colocados $40 \mathrm{~mL}$ de solução saturada de $\mathrm{NaCl}$. O período de envelhecimento foi de 72 horas, em câmara do tipo BOD, a $41^{\circ} \mathrm{C}$ (Panobianco, 2000). Em seguida, foi conduzido o teste de germinação, conforme descrito no item 3.2.1.2, com avaliação única aos 7 dias após a semeadura. Os resultados foram expressos em porcentagem de plântulas normais para cada lote. Foi determinado, também, o grau de umidade das sementes antes e após o período de envelhecimento, para a verificação das condições do teste.

\subsubsection{Teste de deterioração controlada}

Inicialmente, as sementes foram hidratadas por, aproximadamente, 11 horas, até alcançarem $24 \%$ água, através do método da atmosfera úmida (Rossetto, 1995). O controle da captação de água foi efetuado por pesagens $(0,0001)$ sucessivas e pelo cálculo do conteúdo de água em cada pesagem. Quando as sementes alcançaram, aproximadamente, $24 \%$ de água foram

embaladas em sacos plásticos aluminizados, fechados hermeticamente e 
mantidos em câmara fria $\left(10^{\circ} \mathrm{C}\right)$ por 5 dias, para atingir o equilíbrio higroscópico. Após esse período, as sementes foram mantidas em banhomaria, a $45^{\circ} \mathrm{C}$, por 24 horas (Panobianco, 2000). A seguir, esses recipientes foram imersos rapidamente em água fria para reduzir a temperatura e, em seguida, foi conduzido o teste de germinação, conforme descrito no item 3.2.1.2, com avaliação única aos 7 dias após a semeadura. Os resultados foram expressos em porcentagem de plântulas normais para cada lote. Foi determinado, também, o grau de umidade das sementes após o período em banho-maria.

\subsubsection{Teste de tetrazólio}

O método utilizado para a avaliação da viabilidade das sementes foi o definido pela pesquisa, nas etapas 1 e 2, itens 3.2.1.5. e 3.2.2.1. Já, para a avaliação do vigor, as sementes foram classificadas em: 1) viáveis e vigorosas: coloração rosa claro em toda extensão do embrião e do endosperma, com tecidos firmes e túrgidos, sem apresentar lesões visíveis; 2) viáveis e não vigorosas: endosperma e, ou, cotilédones, com menos de $50 \%$ das áreas não coloridas, a extremidade do eixo hipocótilo-radícula pode se apresentar sem coloração, desde que os tecidos estejam firmes e túrgidos, sem lesões visíveis, com possibilidade de originar plântulas normais; 3) não viáveis: mais de 50\% das áreas dos cotilédones e/ou do endosperma não coloridas, ou a ausência de coloração na região da extremidade da radícula, apresentando tecidos flácidos e brancos ou amarelados, sem lesões visíveis, ou com as áreas do endosperma e embrião totalmente sem coloração, indicando a possibilidade de originarem plântulas anormais ou estado metabólico característico de sementes mortas.

Após a avaliação das sementes de tomate pelo teste de tetrazólio, foram tiradas fotografias das sementes viáveis e vigorosas, viáveis não vigorosas e não viáveis dos dois cultivares Débora Max e Acclaim, conforme indicado no item 3.2.1.5. 


\subsubsection{Procedimento estatístico}

Para analisar os dados, de cada um dos cultivares, referentes aos testes de germinação, emergência de plântula (germinação e vigor), tetrazólio (viabilidade e vigor), envelhecimento acelerado e deterioração controlada, foi utilizado o delineamento inteiramente casualizado, com quatro repetições, de acordo com o esquema de análise de variância apresentado na Tabela 9. Os dados de germinação, tetrazólio, envelhecimento acelerado, deterioração controlada e de emergência de plântula foram transformados em arc $\operatorname{sen} \sqrt{x / 100}$. A comparação de médias foi efetuada pelo teste de Tukey $(p<0,05)$. Não foi realizada análise estatística dos dados obtidos para o grau de umidade das sementes. Para execução das análises foi utilizado o Sistema de Análise Estatística para Microcomputadores - SANEST (Zonta \& Machado, 1994).

Tabela 9. Esquema de análise de variância para os testes de germinação, de emergência de plântula (germinação e vigor), de tetrazólio (viabilidade e vigor), de envelhecimento acelerado e de deterioração controlada, para cada cultivar (Fase II).

\begin{tabular}{|c|c|}
\hline Causa de variação & Grau de liberdade \\
\hline Lotes & 2 \\
\hline Resíduo & 9 \\
\hline Total & 11 \\
\hline
\end{tabular}




\section{RESULTADOS E DISCUSSÃO}

\subsection{Fase I - Viabilidade}

\subsubsection{Etapa 1}

\subsubsection{Hidratação das sementes}

Os resultados referentes à captação de água pelas sementes de tomate, $\mathrm{CV}$. Bruna, dos quatro lotes, para a temperatura de $40^{\circ} \mathrm{C}$, entre papel (Tabela 10), indicaram expressivo aumento do teor de água das sementes durante a primeira hora de hidratação, nos demais períodos a variação foi menor. Esse mesmo comportamento foi observado para as sementes submetidas à hidratação direta em água (Tabela 10). No entanto, nesse método o teor de água das sementes foi maior. Considerando o valor médio, para os quatro lotes, em cada condição estudada, os teores de água alcançado pelas sementes, a $40^{\circ} \mathrm{C}$, pelo método entre papel, foram: $37 \%$ após uma hora, $42 \%$ após duas horas, $44 \%$ após três horas, $45 \%$ com quatro horas e $47 \%$ com cinco horas. Já, com a imersão direta em água esses valores foram, respectivamente, para cada período indicado, 40\%, 42\%, 44\%, 47\% e 48\%.

Para a hidratação a $45^{\circ} \mathrm{C}$, tanto entre papel como direta em água (Tabela 11), as sementes absorveram, também, bastante água na primeira hora de hidratação. Nos demais períodos, a variação do grau de umidade das sementes ocorreu de forma semelhante ao indicado para $40^{\circ} \mathrm{C}$. Assim, considerando o valor médio, para os quatro lotes, em cada condição estudada os teores de 
água alcançado pelas sementes, a $45^{\circ} \mathrm{C}$, pelo método entre papel, foram: $38 \%$ após uma hora, $43 \%$ após duas horas, $46 \%$ após três horas, $47 \%$ com quatro horas e $49 \%$ com cinco horas. Já, com a imersão direta em água esses valores foram, respectivamente, para cada período indicado, 41\%, 45\%, 47\% 49\% e $50 \%$.

De maneira geral, independentemente da temperatura e do método utilizado para a hidratação das sementes de tomate, a qualidade dos lotes não influenciou os resultados obtidos.

$\mathrm{Na}$ hidratação a $40^{\circ} \mathrm{C}$ (Tabela 10), o método entre papel promoveu maior uniformidade de absorção de água pelas sementes. Em termos comparativos, na hidratação a $45^{\circ} \mathrm{C}$ (Tabela 11), os dois métodos apresentaram absorção uniforme. No entanto, a hidratação direta em água, para as duas temperaturas, elevou mais acentuadamente o grau de umidade das sementes.

A comparação entre os dois procedimentos, para as duas temperaturas, permite constatar que a variação do grau de umidade entre os lotes foi menor, a $45^{\circ} \mathrm{C}$ que a $40^{\circ} \mathrm{C}$. Na terceira hora de hidratação, por exemplo, a variação a $40^{\circ} \mathrm{C}$ foi de 42,9 a $45,6 \%$, enquanto a $45^{\circ} \mathrm{C}$, foi de 44,8 a $46,4 \%$. Assim, para a temperatura de $45^{\circ} \mathrm{C}$ ocorreu maior estabilidade de absorção de água pelas sementes dos lotes avaliados, em relação à $40^{\circ} \mathrm{C}$. Além disso, o nível de hidratação dos tecidos a $45^{\circ} \mathrm{C}$ foi maior em menor período de tempo, o que é vantajoso para o teste de tetrazólio.

Dessa forma, com base nesses resultados e considerando as indicações de Moore (1977), para um grande número de espécies, o método entre papel foi o estabelecido para a hidratação das sementes de tomate. 
Tabela 10. Teor de água (\%) de quatro lotes de sementes de tomate, cv. Bruna, submetidas a hidratação entre papel e diretamente em água, a $40^{\circ} \mathrm{C}$.

\begin{tabular}{|c|c|c|c|c|c|c|c|c|}
\hline \multicolumn{9}{|c|}{ Teor de água da semente (\%) } \\
\hline \multirow{2}{*}{$\begin{array}{c}\text { Período de } \\
\text { hidratação } \\
\text { (hora), a } \\
40^{\circ} \mathrm{C}\end{array}$} & \multicolumn{4}{|c|}{$\begin{array}{l}\text { Entre papel } \\
\text { Lote }\end{array}$} & \multicolumn{4}{|c|}{$\begin{array}{l}\text { Imersão em água } \\
\text { Lote }\end{array}$} \\
\hline & 1 & 2 & 3 & 4 & 1 & 2 & 3 & 4 \\
\hline 0 & 9,0 & 8,8 & 8,7 & 8,9 & 9,0 & 8,8 & 8,7 & 8,9 \\
\hline 1 & 39,1 & 37,4 & 34,9 & 35,8 & 40,5 & 40,0 & 40,1 & 39,0 \\
\hline 2 & 43,5 & 42,6 & 40,3 & 41,0 & 43,1 & 40,7 & 42,9 & 42,5 \\
\hline 3 & 45,6 & 43,8 & 43,8 & 42,9 & 46,2 & 42,3 & 45,3 & 43,5 \\
\hline 4 & 47,3 & 45,6 & 45,4 & 43,5 & 48,8 & 46,0 & 46,6 & 45,7 \\
\hline 5 & 48,1 & 46,7 & 46,2 & 46,9 & 48,6 & 46,0 & 48,6 & 46,8 \\
\hline
\end{tabular}

Tabela 11. Teor de água (\%) de quatro lotes de sementes de tomate, cv. Bruna, submetidas a hidratação entre papel e diretamente em água, a $45^{\circ} \mathrm{C}$.

\begin{tabular}{ccccccccc}
\hline & \multicolumn{9}{c}{ Teor de água das sementes (\%) } \\
$\begin{array}{c}\text { Período de } \\
\text { hidratação } \\
\text { (hora), a } \\
45^{\circ} \mathrm{C}\end{array}$ & 1 & 2 & 3 & 4 & 1 & 2 & 3 & 4 \\
\hline 0 & 9,0 & 8,8 & 8,7 & 8,9 & 9,0 & 8,8 & 8,7 & 8,9 \\
1 & 39,3 & 39,0 & 38,2 & 36,1 & 40,7 & 41,3 & 42,5 & 39,3 \\
2 & 42,6 & 43,6 & 42,5 & 42,1 & 45,4 & 45,5 & 45,7 & 44,4 \\
3 & 45,4 & 46,4 & 45,7 & 44,8 & 47,6 & 47,5 & 47,8 & 46,5 \\
4 & 48,7 & 48,4 & 46,9 & 45,7 & 49,4 & 49,1 & 49,5 & 47,6 \\
5 & 49,2 & 49,0 & 48,4 & 47,3 & 51,0 & 50,0 & 50,0 & 49,7 \\
\hline
\end{tabular}


A análise geral dos dados do teste de germinação (Tabela 12) indicou, para as três avaliações, a superioridade do lote 1 em relação ao lote 3 , o de menor potencial. Por outro lado, a emergência das plântulas (Tabela 13), para as três avaliações, destacou apenas a inferioridade do lote 3 em relação aos demais.

Para o teste de tetrazólio, conduzido a $40^{\circ} \mathrm{C}$ para a hidratação e a coloração das sementes, os resultados indicaram, nas três avaliações (Tabelas 14, 15 e 16), que os períodos de hidratação de três e quatro horas foram os que permitiram classificação dos lotes semelhante à indicada pelos testes de germinação e de emergência de plântula (Tabelas 12 e 13). Nos períodos de duas horas de hidratação, somente na terceira avaliação, o tratamento 2/3 permitiu a diferenciação do lote 3 como inferior aos demais. Associado aos períodos de hidratação de três e quatro horas os maiores períodos de coloração, ou seja, duas e três horas, também, mostraram a inferioridade do lote 3 em relação aos demais.

Para a temperatura de $45^{\circ} \mathrm{C}$ (Tabelas 17,18 e 19), os períodos de duas horas de hidratação, independentemente do período de coloração, não foram tão eficientes quanto os demais, com relação à classificação do lote 3 como o de potencial fisiológico inferior; apenas na terceira avaliação é que ficou evidente a inferioridade desse lote. Os períodos de três e quatro horas de hidratação classificaram os lotes de forma semelhante ao indicado para $40^{\circ} \mathrm{C}$. Por outro lado, não se verificaram diferenças entre os períodos de coloração, associados aos períodos de hidratação. De maneira geral, para a temperatura de $45^{\circ} \mathrm{C}$, nas três avaliações, os tratamentos $3 / 1,3 / 2$ e $3 / 3$ indicaram que foi possível identificar o lote 1 como o de qualidade superior, os lotes 2 e 4 como os de qualidade intermediária e o 3 como de potencial inferior aos demais. Houve maior estabilidade dos resultados para a classificação do potencial fisiológico dos lotes, nessa temperatura, em relação a de $40^{\circ} \mathrm{C}$. Além disso, o teste de tetrazólio a $45^{\circ} \mathrm{C}$ classificou os lotes de forma semelhante aos resultados encontrados nos testes de germinação e de emergência de plântula. 
Através das imagens fotográficas, provenientes do tratamento $3 / 2$, é possível observar as estruturas vitais da semente viável (Figura 1), coloração completa do embrião e do endosperma e, na Figura 2, a coloração parcial do endosperma e do embrião, que caracteriza a semente não viável.

Considerando a similaridade de resposta entre os resultados de hidratação das sementes nos períodos de três e de quatro horas, para as duas temperaturas, foi realizada mais uma etapa de análise (etapa 2) considerando os períodos de três horas (correspondentes aos tratamentos 3/1, 3/2 e 3/3) e as duas temperaturas $\left(40\right.$ e $\left.45^{\circ} \mathrm{C}\right)$, com a finalidade de estabelecer a associação final pois, esse período reduz o período de tempo para realização do teste de tetrazólio.

Tabela 12. Germinação (\%) de quatro lotes de sementes de tomate, cv. Bruna, em três avaliações.

\begin{tabular}{cccc}
\hline Lote & Germinação (\%) & \\
& $1^{\mathrm{a}}$ avaliação & 2ª $^{\mathrm{a}}$ avaliação & $90 \mathrm{a}$ \\
2 & $99 \mathrm{a}$ & $91 \mathrm{a}$ & $87 \mathrm{a}$ \\
3 & $88 \mathrm{~b}$ & $87 \mathrm{a}$ & $61 \mathrm{~b}$ \\
4 & $73 \mathrm{~b}$ & $67 \mathrm{~b}$ & $87 \mathrm{a}$ \\
$\mathrm{CV}(\%)$ & $89 \mathrm{ab}$ & $81 \mathrm{ab}$ & 7,9 \\
\hline
\end{tabular}

Na coluna, médias seguidas da mesma letra não diferem entre si pelo teste de Tukey a $5 \%$. 
Tabela 13. Emergência de plântula (\%) de quatro lotes de sementes de tomate, cv. Bruna, em três avaliações.

\begin{tabular}{cccc}
\hline Lote & 1a avaliação & $\begin{array}{c}\text { Emergência de plântula (\%) } \\
2^{\mathrm{a}} \text { avaliação }\end{array}$ & $3^{\text {a }}$ avaliação \\
\hline 1 & $91 \mathrm{a}$ & $89 \mathrm{a}$ & $92 \mathrm{a}$ \\
2 & $82 \mathrm{a}$ & $78 \mathrm{a}$ & $86 \mathrm{a}$ \\
3 & $58 \mathrm{~b}$ & $58 \mathrm{~b}$ & $69 \mathrm{~b}$ \\
4 & $83 \mathrm{a}$ & $82 \mathrm{a}$ & $89 \mathrm{a}$ \\
$\mathrm{CV}(\%)$ & 6,9 & 8,1 & 5,8 \\
\hline
\end{tabular}

Na coluna, médias seguidas da mesma letra não diferem entre si pelo teste de Tukey a 5\%.

Tabela 14. Viabilidade (\%), no teste de tetrazólio, de quatro lotes de sementes de tomate, cv. Bruna, hidratadas e imersas em solução de tetrazólio, a $40^{\circ} \mathrm{C}$, na primeira avaliação.

\begin{tabular}{cccccc}
\hline $\begin{array}{c}\text { Períodos de } \\
\text { hidratação e de } \\
\text { imersão em TZ (hora) }\end{array}$ & \multicolumn{5}{c}{$\begin{array}{l}40^{\circ} \mathrm{C} \\
\text { Lote }\end{array}$} \\
\hline $2 / 1$ & $94 \mathrm{aA}$ & $94 \mathrm{aAB}$ & $88 \mathrm{aA}$ & $88 \mathrm{aA}$ & 91 \\
$2 / 2$ & $96 \mathrm{aA}$ & $90 \mathrm{aAB}$ & $82 \mathrm{aA}$ & $88 \mathrm{aA}$ & 90 \\
$2 / 3$ & $97 \mathrm{aA}$ & $94 \mathrm{aAB}$ & $85 \mathrm{aA}$ & $96 \mathrm{aA}$ & 93 \\
$3 / 1$ & $94 \mathrm{aA}$ & $85 \mathrm{aB}$ & $82 \mathrm{aA}$ & $85 \mathrm{aA}$ & 87 \\
$3 / 2$ & $99 \mathrm{aA}$ & $94 \mathrm{abAB}$ & $78 \mathrm{bA}$ & $97 \mathrm{aA}$ & 94 \\
$3 / 3$ & $98 \mathrm{aA}$ & $99 \mathrm{aA}$ & $80 \mathrm{bA}$ & $98 \mathrm{aA}$ & 96 \\
$4 / 1$ & $96 \mathrm{aA}$ & $90 \mathrm{aAB}$ & $64 \mathrm{bA}$ & $94 \mathrm{aA}$ & 88 \\
$4 / 2$ & $94 \mathrm{aA}$ & $94 \mathrm{aAB}$ & $84 \mathrm{aA}$ & $89 \mathrm{aA}$ & 90 \\
$4 / 3$ & $98 \mathrm{aA}$ & $95 \mathrm{aAB}$ & $88 \mathrm{aA}$ & $92 \mathrm{aA}$ & 94 \\
Média & 96 & 93 & 82 & 93 & \\
$\mathrm{CV}(\%)$ & 9,4 & & & & \\
\hline
\end{tabular}

Médias seguidas da mesma letra, minúscula na linha e maiúscula na coluna, não diferem entre si pelo teste de Tukey a $5 \%$. 
Tabela 15. Viabilidade (\%), no teste de tetrazólio, de quatro lotes de sementes de tomate, cv. Bruna, hidratadas e imersas em solução de tetrazólio, a $40^{\circ} \mathrm{C}$, na segunda avaliação.

\begin{tabular}{cccccc}
\hline $\begin{array}{c}\text { Períodos de } \\
\text { hidratação e de } \\
\text { imersão em TZ (hora) }\end{array}$ & \multicolumn{5}{c}{$\begin{array}{l}40^{\circ} \mathrm{C} \\
\text { Lote }\end{array}$} \\
\hline $2 / 1$ & $84 \mathrm{aB}$ & $78 \mathrm{aA}$ & $70 \mathrm{aA}$ & $77 \mathrm{aB}$ & 77 \\
$2 / 2$ & $87 \mathrm{abAB}$ & $75 \mathrm{bA}$ & $70 \mathrm{bA}$ & $95 \mathrm{aA}$ & 83 \\
$2 / 3$ & $85 \mathrm{aB}$ & $87 \mathrm{aA}$ & $73 \mathrm{aA}$ & $88 \mathrm{aAB}$ & 84 \\
$3 / 1$ & $95 \mathrm{aAB}$ & $78 \mathrm{bA}$ & $68 \mathrm{bA}$ & $78 \mathrm{bAB}$ & 82 \\
$3 / 2$ & $85 \mathrm{aB}$ & $88 \mathrm{aA}$ & $77 \mathrm{aA}$ & $80 \mathrm{aAB}$ & 83 \\
$3 / 3$ & $97 \mathrm{aAB}$ & $84 \mathrm{bcA}$ & $65 \mathrm{cA}$ & $87 \mathrm{abAB}$ & 85 \\
$4 / 1$ & $88 \mathrm{aAB}$ & $82 \mathrm{aA}$ & $73 \mathrm{aA}$ & $80 \mathrm{aAB}$ & 81 \\
$4 / 2$ & $97 \mathrm{aAB}$ & $87 \mathrm{abA}$ & $78 \mathrm{bA}$ & $81 \mathrm{bAB}$ & 87 \\
$4 / 3$ & $99 \mathrm{aA}$ & $93 \mathrm{abA}$ & $68 \mathrm{cA}$ & $87 \mathrm{bAB}$ & 89 \\
Média & 92 & 84 & 72 & 84 & \\
CV(\%) & 9,1 & & & & \\
\hline Médias seguidas da mesma letra, minúscula na linha e maiúscula na coluna, não diferem entre \\
si pelo teste de Tukey a 5\%.
\end{tabular}


Tabela 16. Viabilidade (\%), no teste de tetrazólio, de quatro lotes de sementes de tomate, cv. Bruna, hidratadas e imersas em solução de tetrazólio, a $40^{\circ} \mathrm{C}$, na terceira avaliação.

\begin{tabular}{cccccc}
\hline $\begin{array}{c}\text { Períodos de } \\
\text { hidratação e de } \\
\text { imersão em TZ (hora) }\end{array}$ & \multicolumn{5}{c}{$\begin{array}{l}40^{\circ} \mathrm{C} \\
\text { Lote }\end{array}$} \\
\hline $2 / 1$ & $84 \mathrm{aB}$ & $77 \mathrm{aBC}$ & $75 \mathrm{aA}$ & $83 \mathrm{aA}$ & 80 \\
$2 / 2$ & $90 \mathrm{aAB}$ & $88 \mathrm{aAB}$ & $75 \mathrm{aA}$ & $90 \mathrm{aA}$ & 86 \\
$2 / 3$ & $95 \mathrm{aAB}$ & $98 \mathrm{aA}$ & $62 \mathrm{bA}$ & $94 \mathrm{aA}$ & 90 \\
$3 / 1$ & $80 \mathrm{abB}$ & $85 \mathrm{abAB}$ & $67 \mathrm{bA}$ & $88 \mathrm{aA}$ & 81 \\
$3 / 2$ & $95 \mathrm{aAB}$ & $98 \mathrm{aA}$ & $64 \mathrm{bA}$ & $98 \mathrm{aA}$ & 92 \\
$3 / 3$ & $99 \mathrm{aA}$ & $90 \mathrm{bAB}$ & $72 \mathrm{cA}$ & $90 \mathrm{bA}$ & 90 \\
$4 / 1$ & $88 \mathrm{aB}$ & $58 \mathrm{bC}$ & $58 \mathrm{bA}$ & $88 \mathrm{aA}$ & 75 \\
$4 / 2$ & $99 \mathrm{aA}$ & $87 \mathrm{bcAB}$ & $72 \mathrm{cA}$ & $96 \mathrm{abA}$ & 91 \\
$4 / 3$ & $94 \mathrm{aAB}$ & $97 \mathrm{aA}$ & $63 \mathrm{bA}$ & $87 \mathrm{aA}$ & 87 \\
Média & 93 & 89 & 68 & 91 & \\
CV(\%) & 8,7 & & & & \\
\hline Médias seguidas da mesma letra, minúscula na linha e maiúscula na coluna, não diferem entre \\
si pelo teste de Tukey a 5\%.
\end{tabular}


Tabela 17. Viabilidade (\%), no teste de tetrazólio, de quatro lotes de sementes de tomate, cv. Bruna, hidratadas a $45^{\circ} \mathrm{C}$, e imersas em solução de tetrazólio, a $40^{\circ} \mathrm{C}$, na primeira avaliação.

\begin{tabular}{|c|c|c|c|c|c|}
\hline \multirow[t]{2}{*}{$\begin{array}{c}\text { Períodos de } \\
\text { hidratação e de } \\
\text { imersão em TZ (hora) }\end{array}$} & \multicolumn{4}{|c|}{$\begin{array}{l}45^{\circ} \mathrm{C} \\
\text { Lote }\end{array}$} & \multirow[b]{2}{*}{ Média } \\
\hline & 1 & 2 & 3 & 4 & \\
\hline $2 / 1$ & $98 \mathrm{aAB}$ & 82 bA & $79 \mathrm{bA}$ & $78 \mathrm{bA}$ & 86 \\
\hline $2 / 2$ & $95 \mathrm{aAB}$ & $87 \mathrm{abA}$ & $74 \mathrm{bA}$ & $94 \mathrm{aA}$ & 88 \\
\hline $2 / 3$ & 99 aA & $90 \mathrm{bA}$ & $77 \mathrm{bA}$ & $83 \mathrm{bA}$ & 90 \\
\hline $3 / 1$ & 89 aAB & $87 \mathrm{aA}$ & $68 \mathrm{bA}$ & $88 \mathrm{aA}$ & 84 \\
\hline $3 / 2$ & $98 \mathrm{aAB}$ & $87 \mathrm{abA}$ & $72 \mathrm{bA}$ & $87 \mathrm{abA}$ & 87 \\
\hline $3 / 3$ & $94 \mathrm{aAB}$ & $88 \mathrm{aA}$ & $81 \mathrm{aA}$ & $94 \mathrm{aA}$ & 90 \\
\hline $4 / 1$ & $85 \mathrm{aB}$ & $90 \mathrm{aA}$ & $65 \mathrm{bA}$ & $92 \mathrm{aA}$ & 84 \\
\hline $4 / 2$ & $97 \mathrm{aAB}$ & $88 \mathrm{abA}$ & $84 \mathrm{bA}$ & $87 \mathrm{abA}$ & 90 \\
\hline $4 / 3$ & $98 \mathrm{aAB}$ & $94 \mathrm{aA}$ & $75 \mathrm{bA}$ & $87 \mathrm{abA}$ & 90 \\
\hline Média & 95 & 88 & 75 & 88 & \\
\hline $\mathrm{CV}(\%)$ & 8,6 & & & & \\
\hline
\end{tabular}


Tabela 18. Viabilidade (\%), no teste de tetrazólio, de quatro lotes de sementes de tomate, cv. Bruna, hidratadas a $45^{\circ} \mathrm{C}$, e imersas em solução de tetrazólio, a $40^{\circ} \mathrm{C}$, na segunda avaliação.

\begin{tabular}{|c|c|c|c|c|c|}
\hline \multirow[t]{2}{*}{$\begin{array}{c}\text { Períodos de } \\
\text { hidratação e de } \\
\text { imersão em TZ (hora) }\end{array}$} & \multicolumn{4}{|c|}{$\begin{array}{l}45^{\circ} \mathrm{C} \\
\text { Lote }\end{array}$} & \multirow[b]{2}{*}{ Média } \\
\hline & 1 & 2 & 3 & 4 & \\
\hline $2 / 1$ & $98 \mathrm{aAB}$ & $84 \mathrm{bABC}$ & $80 \mathrm{bA}$ & $65 \mathrm{bC}$ & 84 \\
\hline $2 / 2$ & $88 \mathrm{abB}$ & $96 \mathrm{aAB}$ & $75 \mathrm{bA}$ & 86 abABC & 87 \\
\hline $2 / 3$ & 96 aAB & 78 bBC & $63 \mathrm{bA}$ & 75 bBC & 80 \\
\hline $3 / 1$ & $100 \mathrm{aA}$ & $77 \mathrm{bC}$ & $83 \mathrm{bA}$ & $73 \mathrm{bBC}$ & 87 \\
\hline $3 / 2$ & $94 \mathrm{aAB}$ & 87 abABC & $78 \mathrm{bA}$ & 85 abABC & 87 \\
\hline $3 / 3$ & $88 \mathrm{aB}$ & $84 \mathrm{aABC}$ & $70 \mathrm{aA}$ & 85 aABC & 82 \\
\hline $4 / 1$ & $85 \mathrm{aB}$ & 87 aABC & $62 \mathrm{bA}$ & $80 \mathrm{abABC}$ & 79 \\
\hline $4 / 2$ & $97 \mathrm{aAB}$ & 97 aA & $82 \mathrm{bA}$ & $95 \mathrm{abA}$ & 94 \\
\hline $4 / 3$ & $97 \mathrm{aAB}$ & 87 abABC & $77 \mathrm{bA}$ & $88 \mathrm{abAB}$ & 88 \\
\hline Média & 95 & 87 & 75 & 82 & \\
\hline $\mathrm{CV}(\%)$ & 9,2 & & & & \\
\hline
\end{tabular}


Tabela 19. Viabilidade (\%), no teste de tetrazólio, de quatro lotes de sementes de tomate, cv. Bruna, hidratadas a $45^{\circ} \mathrm{C}$ e imersas em solução de tetrazólio, a $40^{\circ} \mathrm{C}$, na terceira avaliação.

\begin{tabular}{|c|c|c|c|c|c|}
\hline \multirow[t]{2}{*}{$\begin{array}{c}\text { Períodos de } \\
\text { hidratação e de } \\
\text { imersão em TZ (hora) }\end{array}$} & \multicolumn{4}{|c|}{$\begin{array}{l}45^{\circ} \mathrm{C} \\
\text { Lote }\end{array}$} & \multirow[b]{2}{*}{ Média } \\
\hline & 1 & 2 & 3 & 4 & \\
\hline $2 / 1$ & $84 \mathrm{abA}$ & $75 \mathrm{abA}$ & $60 \mathrm{bA}$ & $85 \mathrm{aA}$ & 77 \\
\hline $2 / 2$ & $98 \mathrm{aA}$ & $86 \mathrm{abA}$ & $57 \mathrm{cA}$ & 82 bA & 83 \\
\hline $2 / 3$ & $95 \mathrm{aA}$ & 87 aA & $55 \mathrm{bA}$ & 88 aA & 84 \\
\hline $3 / 1$ & $97 \mathrm{aA}$ & $83 \mathrm{abA}$ & $57 \mathrm{cA}$ & $80 \mathrm{bcA}$ & 81 \\
\hline $3 / 2$ & $94 \mathrm{aA}$ & $83 \mathrm{abA}$ & $70 \mathrm{bA}$ & $94 \mathrm{aA}$ & 87 \\
\hline $3 / 3$ & 96 aA & $87 \mathrm{aA}$ & $55 \mathrm{bA}$ & $87 \mathrm{aA}$ & 83 \\
\hline $4 / 1$ & $90 \mathrm{aA}$ & $77 \mathrm{abA}$ & $52 \mathrm{bA}$ & $87 \mathrm{aA}$ & 78 \\
\hline $4 / 2$ & $90 \mathrm{aA}$ & $82 \mathrm{aA}$ & $69 \mathrm{aA}$ & $85 a A$ & 82 \\
\hline $4 / 3$ & $97 \mathrm{aA}$ & $84 a b A$ & $62 \mathrm{bA}$ & $95 \mathrm{aA}$ & 87 \\
\hline Média & 94 & 83 & 60 & 88 & \\
\hline $\mathrm{CV}(\%)$ & 11,1 & & & & \\
\hline
\end{tabular}




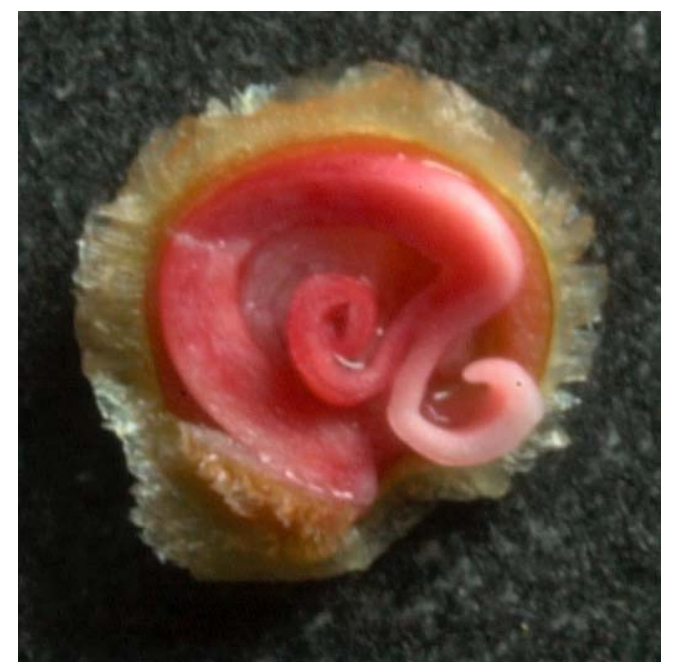

Figura 1 - Semente de tomate, cv. Bruna, viável.

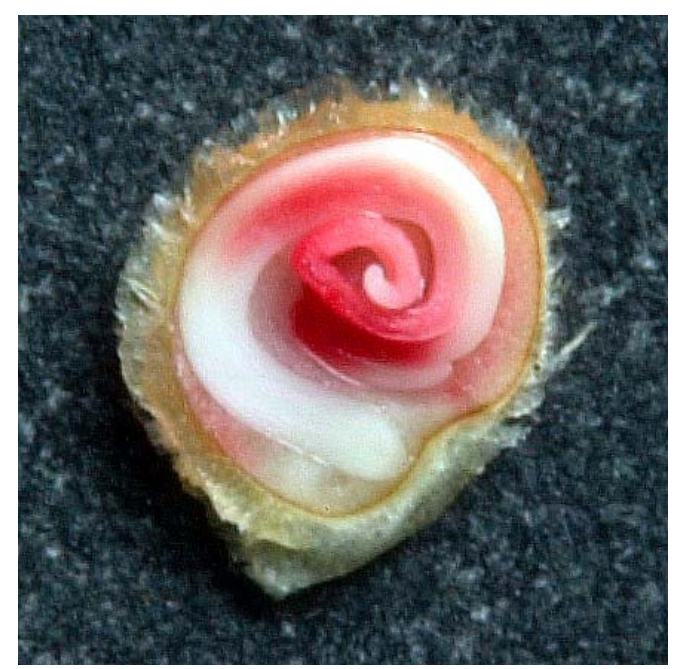

Figura 2 - Semente de tomate, cv. Bruna, não viável. 


\subsubsection{Etapa 2}

Os resultados obtidos no teste de tetrazólio, na etapa 1, indicaram os períodos de hidratação de três e de quatro horas como os mais adequados, devido à facilidade da realização do corte e por terem apresentado resultados (viabilidade) estatisticamente semelhantes aos do teste de germinação, para as duas temperaturas. Assim, para a etapa 2, foram considerados os períodos de três horas (correspondentes aos tratamentos 3/1,3/2 e 3/3, Tabela 4), por reduzirem o período de tempo necessário para realização do teste de tetrazólio e as duas temperaturas $\left(40\right.$ e $\left.45^{\circ} \mathrm{C}\right)$, para estabelecer $\mathrm{o}$ tratamento mais adequado para a condução do teste.

A análise geral dos dados de germinação (Tabela 20) e de emergência de plântula (Tabela 21), nas três avaliações, indicou que os lotes 1,2 e 4 apresentaram nível semelhante de qualidade e, na maior parte dos resultados, não diferiram estatisticamente entre si; já o lote 3 , independentemente do teste aplicado e da etapa considerada, foi classificado como o de menor potencial fisiológico.

Para o teste de tetrazólio (Tabelas 22,23 e 24) com hidratação a $40^{\circ} \mathrm{C}$, os resultados indicaram, nas três avaliações, que os lotes apresentaram classificação semelhante à obtida nos testes de germinação (Tabela 20) e de emergência de plântula (Tabela 21), destacando em todas as avaliações a inferioridade estatística do lote 3 em relação aos demais, principalmente, em relação ao lote 1. A comparação entre os tratamentos 3/1, 3/2 e $3 / 3$, correspondentes aos períodos de três horas de hidratação e de uma, duas e três horas de imersão em solução de tetrazólio, para a temperatura de $40^{\circ} \mathrm{C}$ para a hidratação, nas três avaliações realizadas, não apresentaram diferença estatística significativa.

Para a hidratação a $45^{\circ} \mathrm{C}$ (Tabelas 25,26 e 27), os lotes foram classificados de forma semelhante à verificada a $40^{\circ} \mathrm{C}$ e nos testes de germinação e emergência de plântula, nas três avaliações, indicando que o lote 
1 foi superior ao lote 3 , estatisticamente inferior aos demais. Para essa temperatura de hidratação, os tratamentos $3 / 1,3 / 2$ e $3 / 3$ apresentaram diferença significativa apenas na terceira avaliação, que indicou o período de duas horas para a coloração (3/2) como inferior ao período de uma hora (3/1).

Os resultados do teste de tetrazólio para as duas temperaturas de hidratação, indicaram a superioridade do lote 1 em relação ao lote 3 , nas três avaliações; essa mesma classificação de lotes foi observada nos testes de germinação e de emergência de plântula. Para a maior parte dos resultados, relacionados à comparação dos períodos de coloração (tratamentos 3/1, 3/2 e 3/3), não foram encontradas diferenças significativas. Assim, para o estabelecimento de uma condição foi considerado, também, o exame visual da semente.

Através das imagens fotográficas de sementes provenientes dos tratamentos $3 / 1,3 / 2,3 / 3$, a $40^{\circ} \mathrm{C}$ (Figuras 3 , 3-A e 3-B) e a $45^{\circ} \mathrm{C}$ (Figuras 4 , 4-A e 4-B) é possível observar o aspecto geral das estruturas das sementes classificadas como viáveis, com a coloração completa do embrião e do endosperma. Por outro lado, na Figura 5 constata-se a ausência total de coloração do embrião e do endosperma, caracterizando a semente não viável.

Nas Figuras 3 e $3-\mathrm{A}$, a $40^{\circ} \mathrm{C}$, e 4 e $4-\mathrm{A}$, a $45^{\circ} \mathrm{C}$, apesar das sementes apresentarem tecidos firmes e túrgidos, não houve uniformidade de coloração das estruturas vitais (embrião e endosperma), dificultando a avaliação dos tecidos. Assim, ficou evidenciado que o período de coloração mais adequado para a identificação das estruturas vitais da semente foi o de três horas, tanto a $40^{\circ} \mathrm{C}$ como a $45^{\circ} \mathrm{C}$ (Figuras 3-B e 4-B, respectivamente).

Dessa forma, considerando os resultados dos testes de germinação, de emergência de plântula e de tetrazólio e a avaliação visual dos tecidos do embrião e do endosperma, com o apoio das imagens fotográficas, foi estabelecido que a hidratação das sementes, entre papel, por três horas a $45^{\circ} \mathrm{C}$, seguida da coloração das sementes, em solução de tetrazólio $0,075 \%$, 
por três horas, a $40^{\circ} \mathrm{C}$ é a condição mais adequada para a estimar a viabilidade das sementes de tomate pelo teste de tetrazólio.

Tabela 20. Germinação (\%) de quatro lotes de sementes de tomate, cv. Bruna, em três avaliações.

\begin{tabular}{cccc}
\hline Lote & \multicolumn{3}{c}{ Germinação (\%) } \\
$1^{\text {a- }}$ avaliação & $2^{\text {a }}$ avaliação & $3^{\text {a }}$ avaliação \\
\hline 1 & $92 \mathrm{a}$ & $89 \mathrm{a}$ & $88 \mathrm{a}$ \\
2 & $67 \mathrm{~b}$ & $85 \mathrm{a}$ & $85 \mathrm{a}$ \\
3 & $56 \mathrm{~b}$ & $63 \mathrm{~b}$ & $55 \mathrm{~b}$ \\
4 & $89 \mathrm{a}$ & $86 \mathrm{a}$ & $88 \mathrm{a}$ \\
$\mathrm{CV}(\%)$ & 7,0 & 4,7 & 6,2 \\
\hline
\end{tabular}

Na coluna, médias seguidas da mesma letra não diferem entre si pelo teste de Tukey a $5 \%$.

Tabela 21. Emergência de plântula (\%) de quatro lotes de sementes de tomate, cv. Bruna, em três avaliações.

\begin{tabular}{cccc}
\hline Lote & \multicolumn{3}{c}{$\begin{array}{c}\text { Emergência de plântula (\%) } \\
2^{\text {a }} \text { avaliação }\end{array}$} \\
\hline 1 & $89 \mathrm{a}$ & $91 \mathrm{a}$ & $91 \mathrm{a}$ \\
2 & $84 \mathrm{a}$ & $86 \mathrm{a}$ & $90 \mathrm{a}$ \\
3 & $64 \mathrm{~b}$ & $59 \mathrm{~b}$ & $61 \mathrm{~b}$ \\
4 & $88 \mathrm{a}$ & $91 \mathrm{a}$ & $86 \mathrm{a}$ \\
$\mathrm{CV}(\%)$ & 5,8 & 4,9 & 6,3
\end{tabular}

Na coluna, médias seguidas da mesma letra não diferem entre si pelo teste de Tukey a 5\%. 
Tabela 22. Viabilidade (\%), no teste de tetrazólio, de quatro lotes de sementes de tomate, cv. Bruna, em três combinações de períodos de hidratação e imersão em solução de tetrazólio, a $40^{\circ} \mathrm{C}$, na primeira avaliação.

\begin{tabular}{ccccc}
\hline $40^{\circ} \mathrm{C}$ & \multicolumn{4}{l}{ Períodos de imersão em solução de tetrazólio (hora) } \\
Lote & $3 / 1$ & $3 / 2$ & $3 / 3$ & Média \\
\hline 1 & 89 & 95 & 90 & $92 \mathrm{a}$ \\
2 & 90 & 85 & 88 & $88 \mathrm{a}$ \\
3 & 77 & 70 & 72 & $73 \mathrm{~b}$ \\
4 & 93 & 82 & 97 & $92 \mathrm{a}$ \\
Média & $88 \mathrm{~A}$ & $84 \mathrm{~A}$ & $88 \mathrm{~A}$ & \\
CV(\%) & 9,9 & & & \\
\hline
\end{tabular}

Médias seguidas da mesma letra, minúscula na coluna e maiúscula na linha, não diferem entre si pelo teste de Tukey a $5 \%$.

Tabela 23. Viabilidade (\%), no teste de tetrazólio, de quatro lotes de sementes de tomate, cv. Bruna, em três combinações de períodos de hidratação e imersão em solução de tetrazólio, a $40^{\circ} \mathrm{C}$, na segunda avaliação.

\begin{tabular}{ccccc}
\hline $40^{\circ} \mathrm{C}$ & \multicolumn{4}{l}{ Períodos de imersão em solução de tetrazólio (hora) } \\
Lote & $3 / 1$ & $3 / 2$ & $3 / 3$ & Média \\
\hline 1 & 94 & 98 & 93 & $95 \mathrm{a}$ \\
2 & 88 & 92 & 95 & $92 \mathrm{ab}$ \\
3 & 60 & 73 & 69 & $68 \mathrm{c}$ \\
4 & 85 & 82 & 88 & $85 \mathrm{~b}$ \\
Média & $84 \mathrm{~A}$ & $88 \mathrm{~A}$ & $88 \mathrm{~A}$ & \\
$\mathrm{CV}(\%)$ & 8,1 & & & \\
\hline
\end{tabular}

Médias seguidas da mesma letra, minúscula na coluna e maiúscula na linha, não diferem entre si pelo teste de Tukey a $5 \%$. 
Tabela 24. Viabilidade (\%), no teste de tetrazólio, de quatro lotes de sementes de tomate, cv. Bruna, em três combinações de períodos de hidratação e imersão em solução de tetrazólio, a $40^{\circ} \mathrm{C}$, na terceira avaliação.

\begin{tabular}{ccccc}
\hline \multirow{2}{*}{$0^{\circ} \mathrm{C}$} & \multicolumn{4}{l}{ Períodos de imersão em solução de tetrazólio (hora) } \\
Lote & $3 / 1$ & $3 / 2$ & $3 / 3$ & Média \\
\hline 1 & 92 & 92 & 98 & $94 \mathrm{a}$ \\
2 & 95 & 85 & 85 & $89 \mathrm{a}$ \\
3 & 60 & 65 & 60 & $62 \mathrm{~b}$ \\
4 & 90 & 89 & 92 & $91 \mathrm{a}$ \\
Média & $86 \mathrm{~A}$ & $84 \mathrm{~A}$ & $86 \mathrm{~A}$ & \\
CV(\%) & 12,6 & & & \\
\hline
\end{tabular}

Médias seguidas da mesma letra, minúscula na coluna e maiúscula na linha, não diferem entre si pelo teste de Tukey a $5 \%$.

Tabela 25. Viabilidade (\%), no teste de tetrazólio, de quatro lotes de sementes de tomate, cv. Bruna, em três combinações de períodos de hidratação, a $45^{\circ} \mathrm{C}$, e imersão em solução de tetrazólio, a $40^{\circ} \mathrm{C}$, na primeira avaliação.

\begin{tabular}{ccccc}
\hline \multirow{2}{*}{$45^{\circ} \mathrm{C}$} & \multicolumn{4}{l}{ Períodos de imersão em solução de tetrazólio (hora) } \\
Lote & $3 / 1$ & $3 / 2$ & $3 / 3$ & Média \\
\hline 1 & 92 & 97 & 92 & $94 \mathrm{a}$ \\
2 & 84 & 88 & 79 & $84 \mathrm{~b}$ \\
3 & 63 & 65 & 63 & $64 \mathrm{c}$ \\
4 & 84 & 90 & 87 & $87 \mathrm{ab}$ \\
Média & $82 \mathrm{~A}$ & $87 \mathrm{~A}$ & $82 \mathrm{~A}$ & \\
$\mathrm{CV}(\%)$ & 8,5 & & & \\
\hline
\end{tabular}

Medias seguidas da mesma letra, minúscula na coluna e maiúscula na linha, não diferem entre si pelo teste de Tukey a $5 \%$. 
Tabela 26. Viabilidade (\%), no teste de tetrazólio, de quatro lotes de sementes de tomate, cv. Bruna, em três combinações de períodos de hidratação, a $45^{\circ} \mathrm{C}$, e imersão em solução de tetrazólio, a $40^{\circ} \mathrm{C}$, na segunda avaliação.

\begin{tabular}{ccccc}
\hline \multirow{2}{*}{$45^{\circ} \mathrm{C}$} & \multicolumn{4}{l}{ Períodos de imersão em solução de tetrazólio (hora) } \\
Lote & $3 / 1$ & $3 / 2$ & $3 / 3$ & Média \\
\hline 1 & 92 & 89 & 98 & $93 \mathrm{a}$ \\
2 & 85 & 96 & 90 & $91 \mathrm{a}$ \\
3 & 66 & 57 & 73 & $65 \mathrm{~b}$ \\
4 & 88 & 94 & 92 & $91 \mathrm{a}$ \\
Média & $84 \mathrm{~A}$ & $86 \mathrm{~A}$ & $90 \mathrm{~A}$ & \\
CV(\%) & 9,5 & & & \\
\hline
\end{tabular}

Médias seguidas da mesma letra, minúscula na coluna e maiúscula na linha, não diferem entre si pelo teste de Tukey a $5 \%$.

Tabela 27. Viabilidade (\%), no teste de tetrazólio, de quatro lotes de sementes de tomate, cv. Bruna, em três combinações de períodos de hidratação, a $45^{\circ} \mathrm{C}$, e imersão em solução de tetrazólio, a $40^{\circ} \mathrm{C}$, na terceira avaliação.

\begin{tabular}{ccccc}
\hline \multirow{2}{*}{$45^{\circ} \mathrm{C}$} & \multicolumn{4}{c}{ Período de imersão em solução de tetrazólio (hora) } \\
Lote & $3 / 1$ & $3 / 2$ & $3 / 3$ & Média \\
\hline 1 & 94 & 84 & 94 & $91 \mathrm{a}$ \\
2 & 92 & 73 & 83 & $84 \mathrm{a}$ \\
3 & 64 & 58 & 47 & $56 \mathrm{~b}$ \\
4 & 90 & 90 & 86 & $89 \mathrm{a}$ \\
Média & $87 \mathrm{~A}$ & $78 \mathrm{~B}$ & $80 \mathrm{AB}$ & \\
$\mathrm{CV}(\%)$ & 10,1 & & & \\
\hline
\end{tabular}

Médias seguidas da mesma letra, minúscula na coluna e maiúscula na linha, não diferem entre si pelo teste de Tukey a $5 \%$. 


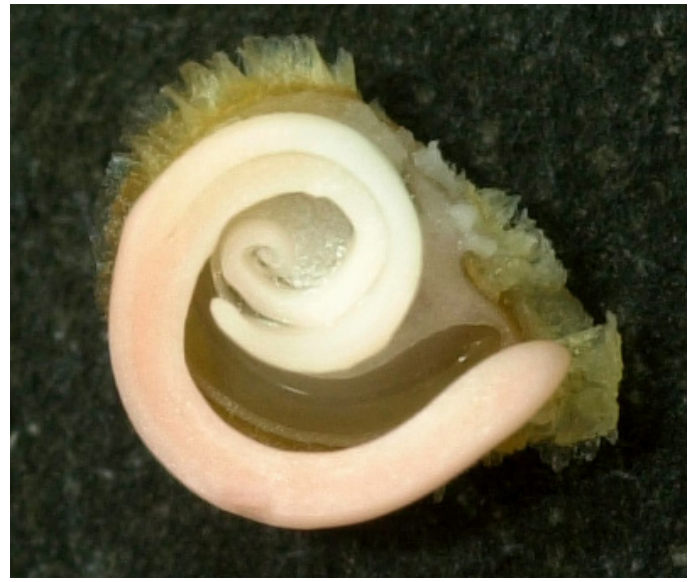

Figura 3 - Semente viável de tomate, cv. Bruna (tratamento 3/1, a $40^{\circ} \mathrm{C}$ ).

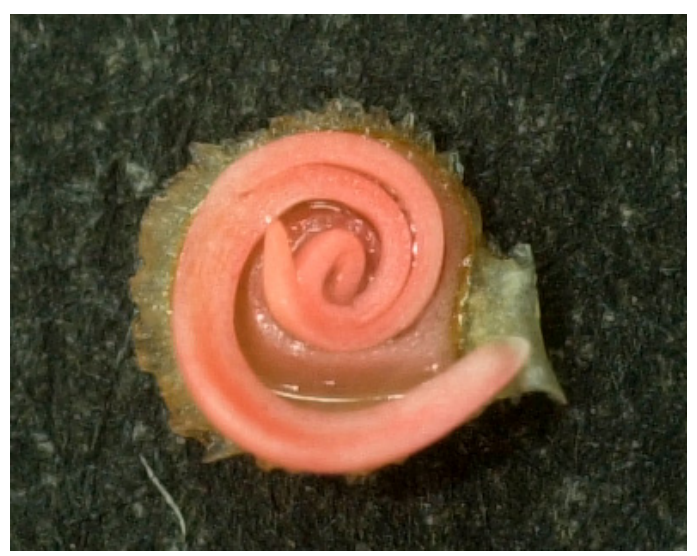

Figura 3-A - Semente viável de tomate, cv. Bruna (tratamento 3/2, a $40^{\circ} \mathrm{C}$ ).

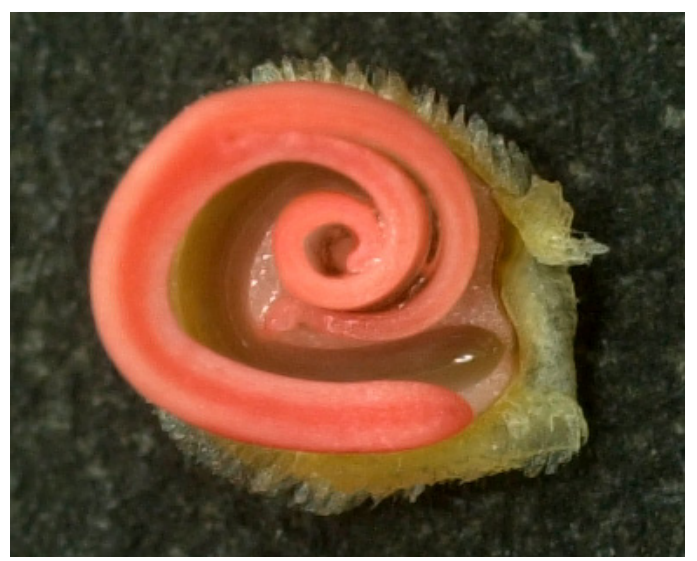

Figura 3-B - Semente viável de tomate, cv. Bruna (tratamento $3 / 3$, a $40^{\circ} \mathrm{C}$ ). 


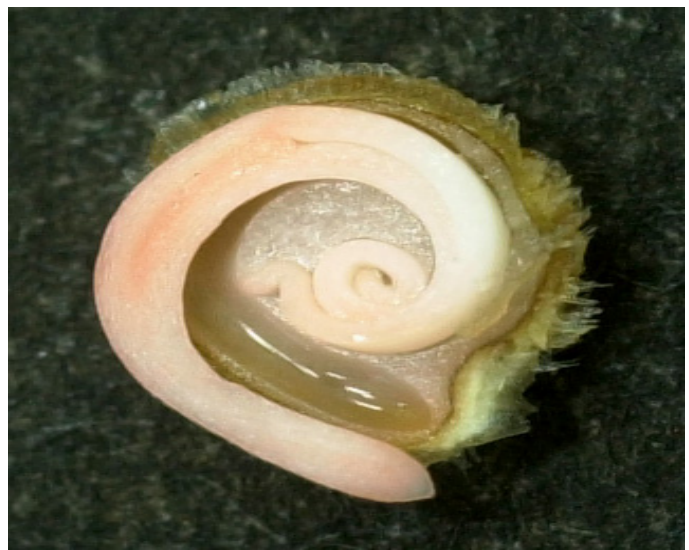

Figura 3 - Semente viável de tomate, cv. Bruna (tratamento 3/1, a $45^{\circ} \mathrm{C}$ ).

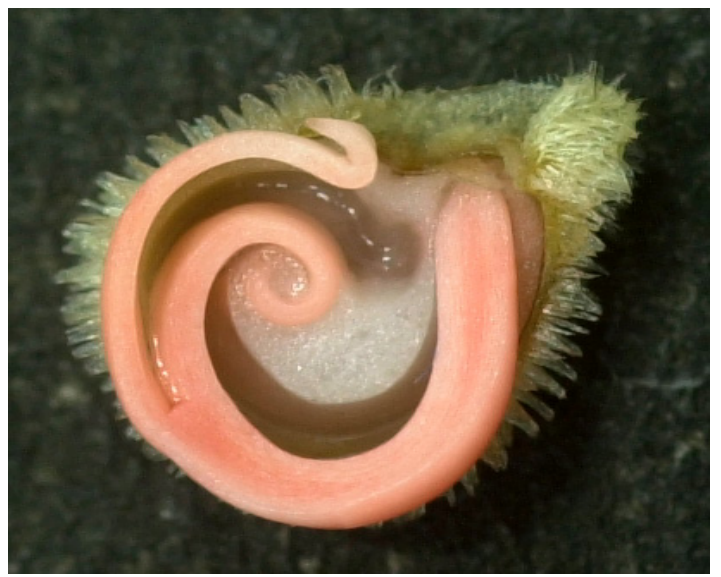

Figura 3-A - Semente viável de tomate, cv. Bruna (tratamento 3/2, a $45^{\circ} \mathrm{C}$ ).

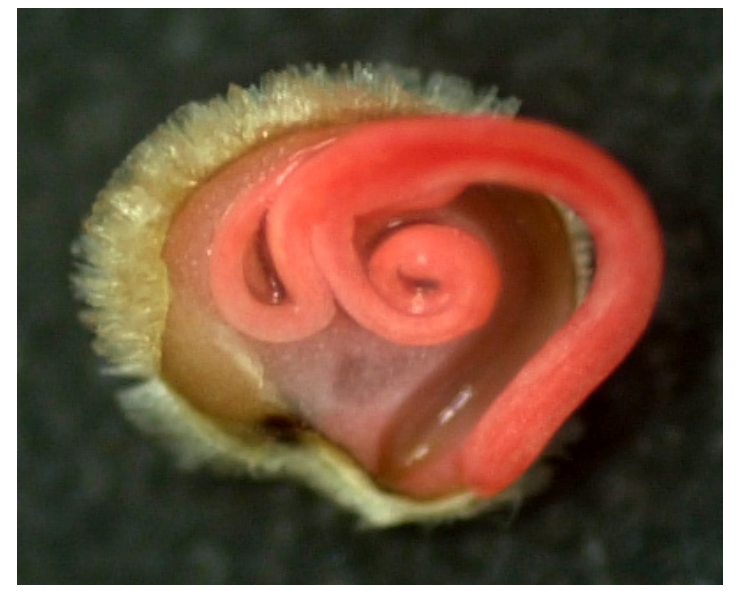

Figura 3-B - Semente viável de tomate, cv. Bruna (tratamento $3 / 3$, a $45^{\circ} \mathrm{C}$ ). 


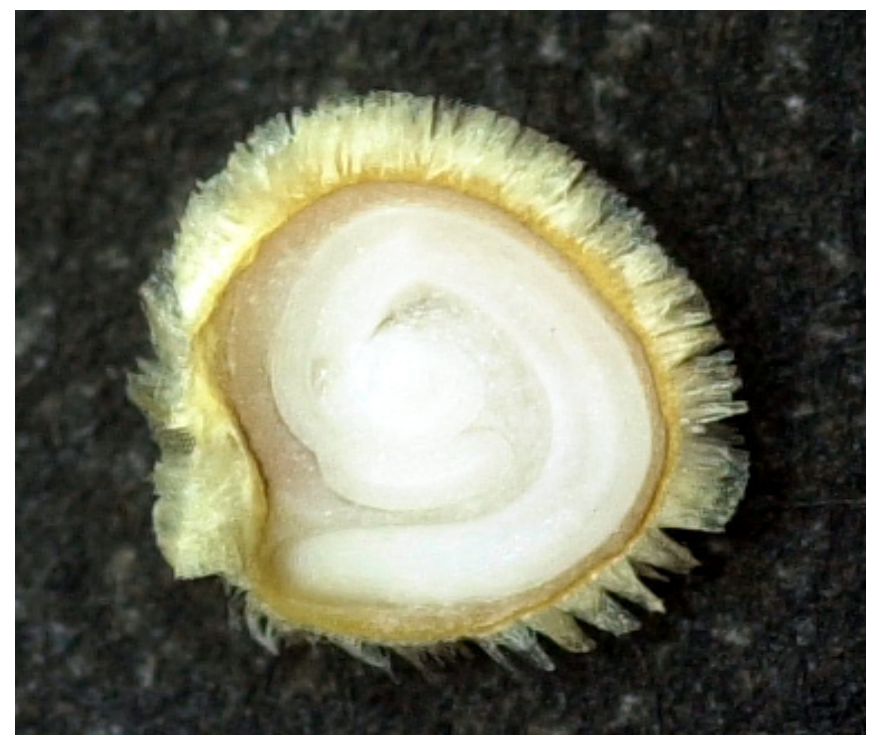

Figura 5 - Semente não viável de tomate cv. Bruna. 


\subsubsection{Etapa 3}

Nessa etapa foram estabelecidas comparações entre as indicações das Regras para Análise de Sementes - R.A.S. (BRASIL, 1992) e a metodologia proposta por essa pesquisa, para a realização do teste de tetrazólio.

O teste de germinação (Tabela 28 ) indicou, para as três avaliações, a qualidade superior do lote 1 em relação aos lotes 2 e 3, com o 2 apresentando germinação superior ao 3 e o lote 4 nível intermediário de qualidade mas, estatisticamente superior ao lote 3.

O teste de emergência de plântula indicou, para as três avaliações (Tabela 29), que os lotes 1, 2 e 4 não diferiram estatisticamente entre si e apresentaram qualidade superior à do lote 3 , à semelhança do verificado no teste de germinação (Tabela 28).

Para o teste de tetrazólio, como viabilidade, utilizando o método proposto pelas Regras (Tabelas 30,31 e 32 ), os resultados indicaram, para as três avaliações, que os lotes apresentaram classificação semelhante à obtida nos testes de germinação (Tabela 28) e de emergência de plântula (Tabela 29), destacando, principalmente, o potencial fisiológico superior do lote 1 em relação ao 3. Os dados correspondentes aos períodos de imersão em solução de tetrazólio (Tabelas 30, 31 e 32) indicaram que houve redução significativa da viabilidade das sementes, principalmente, nos períodos de cinco e de seis horas; nesses tratamentos, a tonalidade de coloração dos tecidos passou de rosa claro à escuro, dificultando a caracterização das sementes em viáveis ou não.

Para a avaliação da viabilidade das sementes pelo teste de tetrazólio utilizando a metodologia definida na etapa 2 (Tabela 33), os resultados destacaram, nas três avaliações, o maior potencial fisiológico do lote 1 e o menor para o lote 3 e os demais (lotes 2 e 4 ) como os de qualidade intermediária; essa mesma classificação de lotes foi observada nos testes de 
germinação (Tabela 28), de emergência de plântula (Tabela 29) e de tetrazólio (Tabelas 30, 31 e 32).

Os resultados do teste de tetrazólio, como viabilidade, para as duas metodologias utilizadas, apresentaram classificação semelhante dos lotes quando comparados aos dos testes de germinação e de emergência de plântula. Portanto, a metodologia proposta por esta pesquisa tem a mesma eficiência, para estimar a viabilidade das sementes de tomate, que a metodologia indicada pelas Regras para Análise de Sementes (Brasil, 1992), com a vantagem de reduzir o período de hidratação das sementes. Além disso, apesar da pesquisa não ter incluído esse estudo, é possível inferir que há a possibilidade de reduzir a concentração da solução de tetrazólio uma vez que, as regras indicam que a concentração deve ser $0,5 \%$ ou $1 \%$.

Considerando os períodos de coloração das sementes, estabelecidos pelas Regras para Análise de Sementes (Brasil, 1992), o de três horas foi o que proporcionou as condições mais favoráveis de coloração para a avaliação pois, à medida que aumentou o período de imersão das sementes na solução de tetrazólio, intensificou-se a coloração dos tecidos das sementes, de rosa claro para escuro, como pode ser observado nas Figuras 6, 6-A, 6-B e 6-C, e, consequentemente, ocorreu maior variação de resultados entre as avaliações.

Através das imagens fotográficas das sementes provenientes dos tratamentos três horas (Figura 6), quatro horas (Figura 6-A), cinco horas (Figura 6-B) e seis horas (Figura 6-C) de coloração a $30^{\circ} \mathrm{C}$, em solução de tetrazólio a 0,5\%, pelo método indicado nas Regras, e das Figuras 7 e $7-\mathrm{A}$, utilizando o método definido nessa pesquisa (três horas de coloração a $40^{\circ} \mathrm{C}$, em solução de tetrazólio a $0,075 \%$ ), pode-se observar o aspecto geral das estruturas das sementes classificadas como viáveis, coloração rosa claro em toda extensão do embrião e endosperma com os tecidos firmes e túrgidos, sem apresentar lesões visíveis (Figuras 6-B, 6-C, 7 e 7-A), ou com tecidos firmes e túrgidos não coloridos na extremidade da radícula (Figuras 6 e 6-A). Na Figura 8 são mostradas as características das sementes não viáveis, mais de $50 \%$ das áreas 
dos cotilédones e endosperma não coloridas, com tecidos flácidos e brancos; na Figura 8-A, constata-se a ausência total de coloração de toda a área interna da semente (embrião e endosperma), com tecidos flácidos, caracterizando a semente morta.

Tabela 28. Germinação (\%) de quatro lotes de sementes de tomate, cv. Bruna, em três avaliações.

\begin{tabular}{cccc}
\hline Lote & $1^{\text {a }}$ avaliação & $\begin{array}{c}\text { Germinação (\%) } \\
2^{-} \text {avaliação }\end{array}$ & $3^{-}$avaliação \\
\hline 1 & $82 \mathrm{a}$ & $84 \mathrm{a}$ & $82 \mathrm{a}$ \\
2 & $77 \mathrm{~b}$ & $78 \mathrm{~b}$ & $76 \mathrm{~b}$ \\
3 & $58 \mathrm{c}$ & $52 \mathrm{c}$ & $55 \mathrm{c}$ \\
4 & $80 \mathrm{ab}$ & $81 \mathrm{ab}$ & $78 \mathrm{ab}$ \\
$\mathrm{CV}(\%)$ & 2,8 & 3,3 & 3,0 \\
\hline
\end{tabular}

Na coluna, médias seguidas da mesma letra não diferem entre si pelo teste de Tukey a $5 \%$.

Tabela 29. Emergência de plântula (\%) de quatro lotes de sementes de tomate, cv. Bruna, em três avaliações.

\begin{tabular}{cccc}
\hline Lote & 1a avaliação & $\begin{array}{c}\text { Emergência de plântula (\%) } \\
2^{\underline{a}} \text { avaliação }\end{array}$ & $3^{\text {a }}$ avaliação \\
\hline 1 & $87 \mathrm{a}$ & $86 \mathrm{a}$ & $89 \mathrm{a}$ \\
2 & $84 \mathrm{a}$ & $85 \mathrm{a}$ & $84 \mathrm{a}$ \\
3 & $53 \mathrm{~b}$ & $55 \mathrm{~b}$ & $51 \mathrm{~b}$ \\
4 & $83 \mathrm{a}$ & $83 \mathrm{a}$ & $87 \mathrm{a}$ \\
$\mathrm{CV}(\%)$ & 7,8 & 5,9 & 6,8
\end{tabular}

Na coluna, médias seguidas da mesma letra não diferem entre si pelo teste de Tukey a $5 \%$. 
Tabela 30. Viabilidade (\%), no teste de tetrazólio, de quatro lotes de sementes de tomate, cv. Bruna, hidratadas por 18 horas a $30^{\circ} \mathrm{C}$, em quatro períodos de imersão em solução de tetrazólio $0,5 \%$, a $30^{\circ} \mathrm{C}$, na primeira avaliação.

\begin{tabular}{cccccc}
\hline \multirow{2}{*}{ Lote } & \multicolumn{5}{c}{ Período de imersão em solução de tetrazólio (hora) } \\
& 3 & 4 & 5 & 6 & Média \\
\hline 1 & 92 & 88 & 84 & 84 & $87 \mathrm{a}$ \\
2 & 81 & 87 & 79 & 80 & $82 \mathrm{~b}$ \\
3 & 62 & 60 & 62 & 58 & $61 \mathrm{c}$ \\
4 & 89 & 85 & 79 & 80 & $84 \mathrm{ab}$ \\
Média & $82 \mathrm{~A}$ & $81 \mathrm{AB}$ & $77 \mathrm{BC}$ & $76 \mathrm{C}$ & \\
CV(\%) & 5,3 & & & & \\
\hline
\end{tabular}

Médias seguidas da mesma letra minúscula na coluna e maiúscula na linha não diferem entre si pelo teste de Tukey a $5 \%$.

Tabela 31. Viabilidade (\%), no teste de tetrazólio, de quatro lotes de sementes de tomate, cv. Bruna, hidratadas por 18 horas a $30^{\circ} \mathrm{C}$, em quatro períodos de imersão em solução de tetrazólio $0,5 \%$, a $30^{\circ} \mathrm{C}$, na segunda avaliação.

\begin{tabular}{cccccc}
\hline \multirow{2}{*}{ Lote } & \multicolumn{5}{c}{ Período de imersão em solução de tetrazólio (hora) } \\
& 3 & 4 & 5 & 6 & Média \\
\hline 1 & 93 & 90 & 91 & 86 & $90 \mathrm{a}$ \\
2 & 85 & 84 & 84 & 83 & $84 \mathrm{~b}$ \\
3 & 62 & 60 & 61 & 57 & $60 \mathrm{c}$ \\
4 & 89 & 84 & 86 & 84 & $86 \mathrm{~b}$ \\
Média & $84 \mathrm{~A}$ & $81 \mathrm{AB}$ & $82 \mathrm{AB}$ & $79 \mathrm{~B}$ & \\
$\mathrm{CV}(\%)$ & 5,9 & & & & \\
\hline
\end{tabular}

Médias seguidas da mesma letra minúscula na coluna e maiúscula na linha não diferem entre si pelo teste de Tukey a $5 \%$. 
Tabela 32. Viabilidade (\%), no teste de tetrazólio, de quatro lotes de sementes de tomate, cv. Bruna, hidratadas por 18 horas a $30^{\circ} \mathrm{C}$, em quatro períodos de imersão em solução de tetrazólio $0,5 \%$, a $30^{\circ} \mathrm{C}$, na terceira avaliação.

\begin{tabular}{cccccc}
\hline \multirow{2}{*}{ Lote } & \multicolumn{5}{c}{ Período de imersão em solução de tetrazólio (hora) } \\
& 3 & 4 & 5 & 6 & Média \\
\hline 1 & 89 & 88 & 88 & 80 & $87 \mathrm{a}$ \\
2 & 88 & 81 & 81 & 80 & $83 \mathrm{~b}$ \\
3 & 61 & 61 & 60 & 58 & $60 \mathrm{c}$ \\
4 & 87 & 82 & 83 & 80 & $83 \mathrm{~b}$ \\
Média & $82 \mathrm{~A}$ & $79 \mathrm{~B}$ & $80 \mathrm{~B}$ & $75 \mathrm{C}$ & \\
CV(\%) & 4,0 & & & & \\
\hline
\end{tabular}

Médias seguidas da mesma letra minúscula na coluna e maiúscula na linha não diferem entre si pelo teste de Tukey a $5 \%$.

Tabela 33. Viabilidade (\%), no teste de tetrazólio, de quatro lotes de sementes de tomate, cv. Bruna, hidratadas durante 3 horas, a $45^{\circ} \mathrm{C}$, e imersas em solução de tetrazólio $0,075 \%$, a $40^{\circ} \mathrm{C}$, em três avaliações.

\begin{tabular}{cccc}
\hline Lote & 1a avaliação & $\begin{array}{c}\text { Viabilidade (\%) } \\
2^{\text {a }} \text { avaliação }\end{array}$ & $3^{\text {a }}$ avaliação \\
\hline 1 & $88 \mathrm{a}$ & $83 \mathrm{a}$ & $85 \mathrm{a}$ \\
2 & $81 \mathrm{~b}$ & $78 \mathrm{~b}$ & $80 \mathrm{~b}$ \\
3 & $62 \mathrm{c}$ & $59 \mathrm{c}$ & $61 \mathrm{c}$ \\
4 & $85 \mathrm{ab}$ & $82 \mathrm{a}$ & $84 \mathrm{a}$ \\
$\mathrm{CV}(\%)$ & 3,3 & 1,7 & 2,2 \\
\hline
\end{tabular}

Na coluna, médias seguidas da mesma letra não diferem entre si pelo teste de Tukey a $5 \%$. 

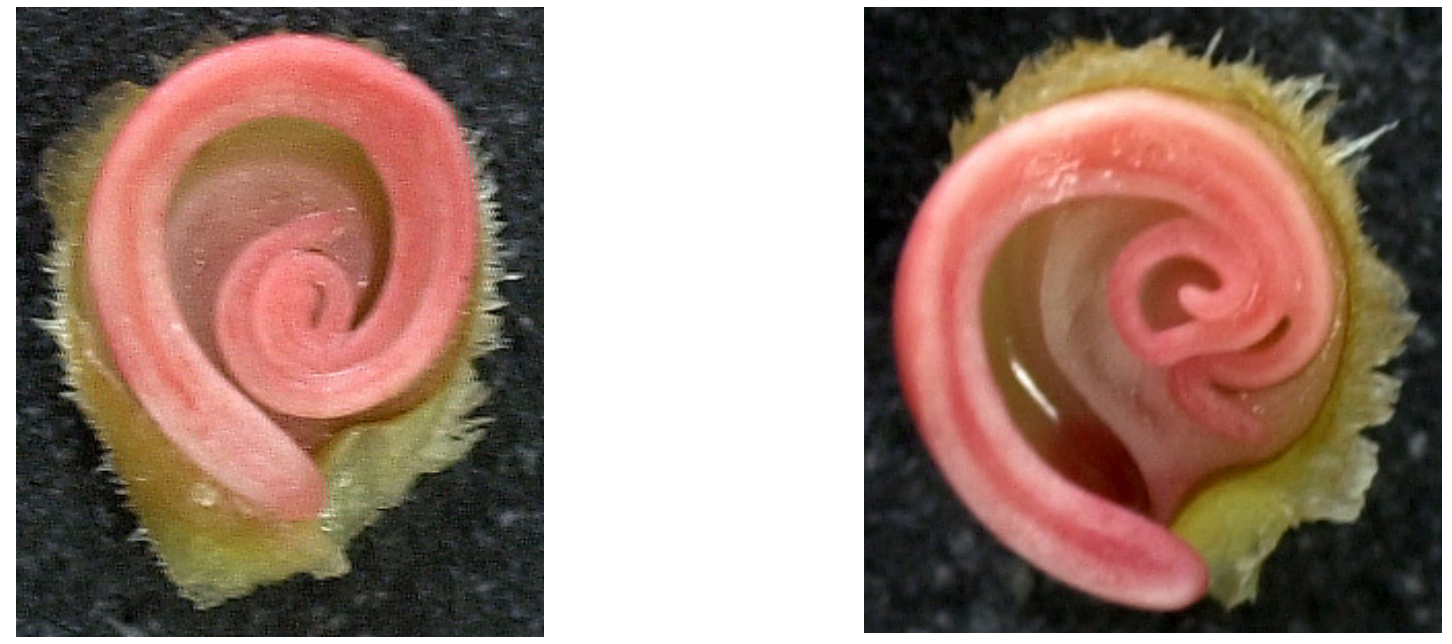

Figuras 6 e 6-A - Sementes viáveis de tomate, cv. Bruna, hidratadas por 18 horas a $30^{\circ} \mathrm{C}$ e mantidas em solução de $\mathrm{TZ} 0,5 \%$, a $30^{\circ} \mathrm{C}$, por 3 e 4 horas.
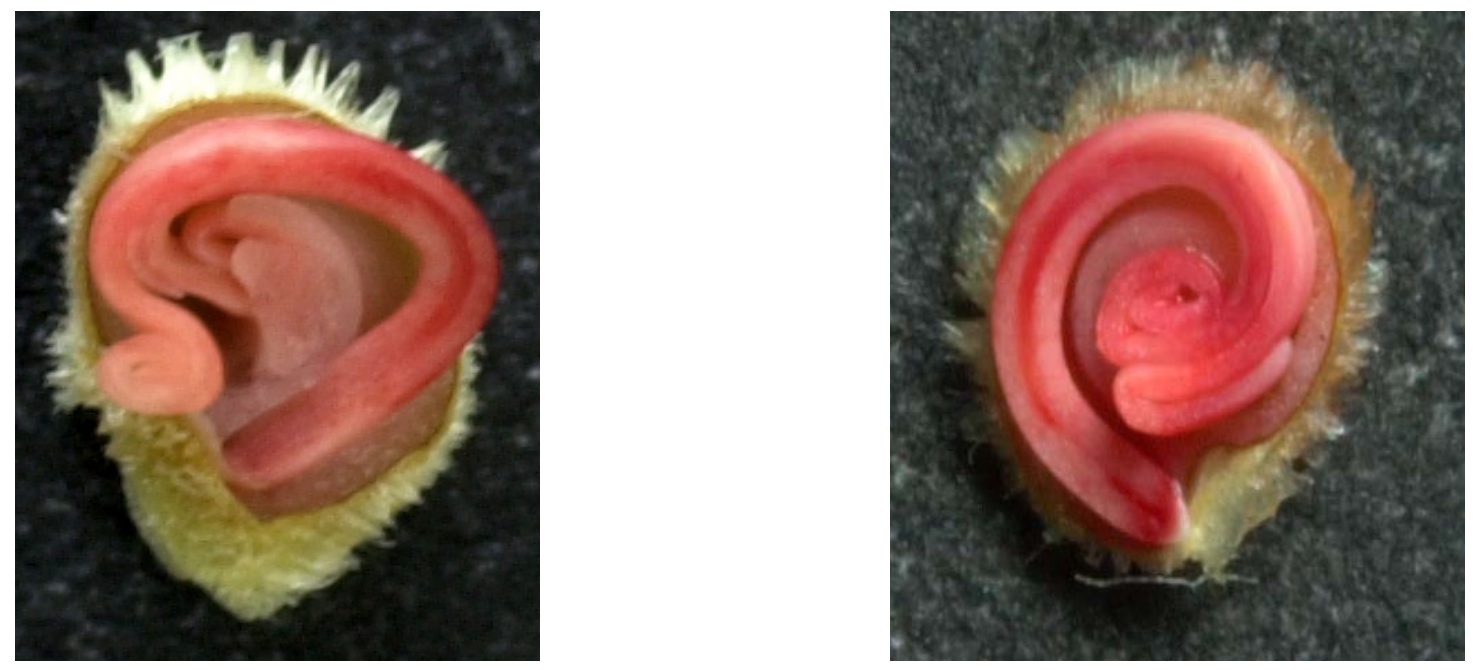

Figuras 6-B e 6-C - Sementes viáveis de tomate, cv. Bruna, hidratadas por 18 horas a $30^{\circ} \mathrm{C}$ e mantidas em solução de $\mathrm{TZ} 0,5 \%$, a $30^{\circ} \mathrm{C}$, por 5 e 6 horas. 

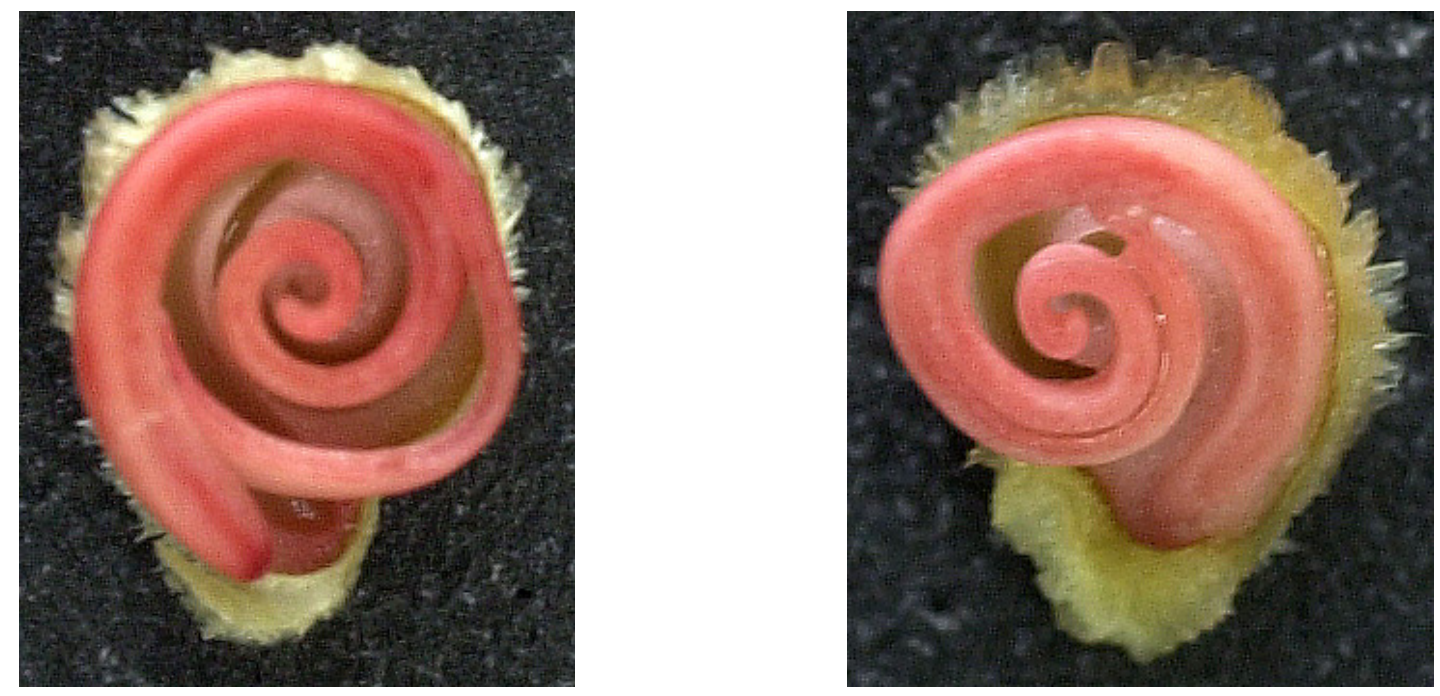

Figuras 7 e 7-A - Sementes viáveis de tomate, cv. Bruna, hidratadas por 3 horas a $45^{\circ} \mathrm{C}$ e mantidas em solução de $\mathrm{TZ} 0,075 \%$, a $40^{\circ} \mathrm{C}$, por 3 horas.
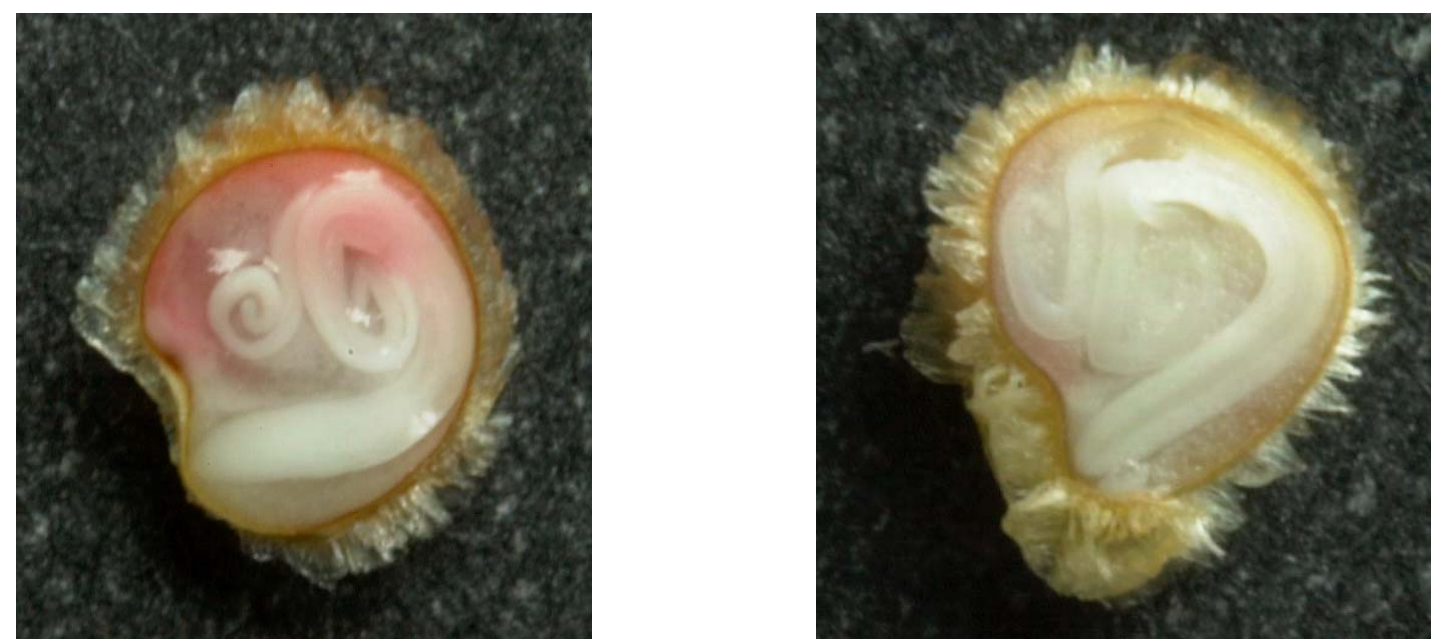

Figuras 8 e 8-A - Sementes de tomate não viáveis, cv. Bruna, hidratadas por 3 horas a $45^{\circ} \mathrm{C}$ e mantidas em solução de $\mathrm{TZ} 0,075 \%$, a $40^{\circ} \mathrm{C}$, por 3 horas. 


\subsection{Fase II - Viabilidade e Vigor}

Para verificar a eficiência do método definido na etapa 2 (viabilidade das sementes pelo teste de tetrazólio) e a possibilidade de serem estabelecidos critérios de avaliação para estimar o vigor das sementes de tomate, foram utilizados os cultivares Débora Max (lotes 1, 2 e 3) e Acclaim (lotes 4, 5 e 6) para a condução da etapa 4 . As sementes foram também avaliadas pelos testes de germinação, de emergência de plântula, de envelhecimento acelerado e de deterioração controlada.

Para o cv. Débora Max, na primeira avaliação (Tabela 34), os resultados dos testes germinação e de tetrazólio indicaram que o lote 2 superou em qualidade o 3 mas, no entanto, esses não mostraram diferença significativa em relação ao lote 1; para o teste de emergência de plântula, não houve diferenças significativas entre os lotes. Os dados dos testes da segunda e terceira avaliações, para o cv. Débora Max, mostraram que o método proposto na pesquisa para o teste de tetrazólio promoveu a mesma ordenação dos lotes que a estabelecida pelos testes de germinação e emergência de plântula (Tabelas 35 e 36$)$.

Com relação à estimativa do vigor das sementes, nas três avaliações (Tabelas 34, 35 e 36), o teste de tetrazólio (vigor) estabeleceu a mesma ordenação para os lotes que à obtida pelos testes de envelhecimento acelerado, deterioração controlada e emergência de plântula, indicando que os períodos de hidratação e de coloração e os critérios de avaliação propostos nessa pesquisa são eficientes.

Para as sementes de tomate do cultivar Acclaim, para as três avaliações (Tabelas 37, 38 e 39), a classificação estatística para os lotes 4, 5 e 6 foi a mesma para os testes que estimam a viabilidade das sementes (germinação, tetrazólio e emergência de plântula) e os de vigor, com exceção do resultado do teste de tetrazólio (viabilidade), na segunda avaliação. 
Os resultados obtidos indicaram que o teste de tetrazólio pode ser utilizado para estimar a viabilidade e o vigor da sementes de tomate. Para tanto, as sementes devem ser hidratadas, entre papel, por três horas, à temperatura de $45^{\circ} \mathrm{C}$ e, em seguida, imersas em solução de tetrazólio $0,075 \%$, a $45^{\circ} \mathrm{C}$, por três horas. Esses resultados possibilitam a redução do período de tempo requerido para a realização do teste, agilizando a obtenção dos resultados.

Pesquisas conduzidas com sementes de cenoura (Andrade et al., 1996), de feijão-de-vagem (Bhéring et al., 1999) e de abóbora (Dias et al., 2001) mostraram, também, que é possível estabelecer condições mais favoráveis para a realização do teste de tetrazólio, para estimar a viabilidade. Por outro lado, além da viabilidade, esse teste é indicado para estimar o vigor de sementes de feijão-de-vagem (Bhéring et al., 1999) e de abóbora (Dias et al., 2001).

Através das imagens fotográficas das sementes avaliadas pelo teste de tetrazólio, para os cultivares Débora Max e Acclaim, podem ser observadas as sementes que foram classificadas em viáveis vigorosas, viáveis não vigorosas e não viáveis. As sementes viáveis vigorosas apresentaram endosperma e embrião íntegros, com coloração rosa claro em 100\% das áreas, sem lesões visíveis e com os tecidos túrgidos e firmes (Figuras 9 e 10). Por outro lado, foram consideradas sementes viáveis não vigorosas aquelas que apresentaram menos de $50 \%$ das áreas do endosperma e/ou dos cotilédones, ou apenas com a extremidade da radícula, com ausência de coloração, mas com tecidos firmes e túrgidos (Figuras 9-A e 10-A). As sementes não viáveis tinham $50 \%$ ou mais das áreas do endosperma e do embrião com tecidos não coloridos e flácidos (Figuras 9-B e 10-B).

As características das sementes viáveis e não viáveis, mostradas na fotografias, podem auxiliar a avaliação da semente, contribuir para uniformizar a interpretação do teste e, consequentemente, possibilitar a padronização dos critérios de avaliação, com reflexos positivos para a comparação de resultados obtidos pelos analistas. 
Tabela 34. Viabilidade (\%): germinação (G), tetrazólio (TZ) e emergência de plântula (EP) e vigor (\%): envelhecimento acelerado (EA), deterioração controlada (DC) e emergência de plântula (EP), de três lotes de sementes de tomate, cv. Débora Max, na primeira avaliação.

\begin{tabular}{|c|c|c|c|c|c|c|c|}
\hline \multicolumn{4}{|c|}{ Viabilidade } & \multicolumn{4}{|c|}{ Vigor } \\
\hline Lote & TG & TZ & EP & EA & DC & EP & TZ \\
\hline 1 & $92 \mathrm{ab}$ & $98 \mathrm{ab}$ & $97 \mathrm{a}$ & $77 \mathrm{~b}$ & $83 \mathrm{~b}$ & $82 \mathrm{~b}$ & $90 \mathrm{~b}$ \\
\hline 2 & $94 \mathrm{a}$ & $100 \mathrm{a}$ & $100 a$ & $85 a$ & $92 \mathrm{a}$ & $92 \mathrm{a}$ & 96 a \\
\hline 3 & $91 \mathrm{~b}$ & $95 \mathrm{~b}$ & 96 a & $59 \mathrm{c}$ & $65 c$ & $70 \mathrm{c}$ & $79 c$ \\
\hline$C V(\%)$ & 2,2 & 6,1 & 8,3 & 2,9 & 4,7 & 3,7 & 3,0 \\
\hline
\end{tabular}

Na coluna, médias seguidas da mesma letra não diferem entre si pelo teste de Tukey a $5 \%$.

Tabela 35. Viabilidade (\%): germinação (G), tetrazólio (TZ) e emergência de plântula (EP) e vigor (\%): envelhecimento acelerado (EA), deterioração controlada (DC) e emergência de plântula (EP), de três lotes de sementes de tomate, cv. Débora Max, na segunda avaliação.

\begin{tabular}{|c|c|c|c|c|c|c|c|}
\hline \multicolumn{4}{|c|}{ Viabilidade } & \multicolumn{4}{|c|}{ Vigor } \\
\hline Lote & TG & $\mathrm{TZ}$ & EP & EA & DC & EP & $\mathrm{TZ}$ \\
\hline 1 & $93 a$ & $100 \mathrm{a}$ & 99 a & $77 \mathrm{~b}$ & $82 \mathrm{~b}$ & $83 \mathrm{~b}$ & $90 \mathrm{~b}$ \\
\hline 2 & $95 \mathrm{a}$ & $100 a$ & $98 \mathrm{a}$ & $86 a$ & $94 \mathrm{a}$ & $91 \mathrm{a}$ & $95 a$ \\
\hline 3 & $90 \mathrm{a}$ & 96 a & $95 \mathrm{a}$ & $60 \mathrm{c}$ & $64 \mathrm{c}$ & $73 c$ & $79 c$ \\
\hline CV $(\%)$ & 5,0 & 8,3 & 7,5 & 4,5 & 5,2 & 3,8 & 1,4 \\
\hline
\end{tabular}

Na coluna, médias seguidas da mesma letra não diferem entre si pelo teste de Tukey a $5 \%$. 
Tabela 36. Viabilidade (\%): germinação (G), tetrazólio (TZ) e emergência de plântula (EP) e vigor (\%): envelhecimento acelerado (EA), deterioração controlada (DC) e emergência de plântula (EP), de três lotes de sementes de tomate, cv. Débora Max, na terceira avaliação.

\begin{tabular}{cccccccc}
\hline \multirow{2}{*}{ Lote } & \multicolumn{2}{c}{ Viabilidade } & \multicolumn{4}{c}{ Vigor } \\
& $\ldots \ldots$ & TZ & EP & EA & DC & EP & TZ \\
1 & $93 \mathrm{a}$ & $100 \mathrm{a}$ & $94 \mathrm{a}$ & $78 \mathrm{~b}$ & $84 \mathrm{~b}$ & $82 \mathrm{~b}$ & $88 \mathrm{~b}$ \\
2 & $96 \mathrm{a}$ & $99 \mathrm{a}$ & $96 \mathrm{a}$ & $86 \mathrm{a}$ & $92 \mathrm{a}$ & $91 \mathrm{a}$ & $94 \mathrm{a}$ \\
3 & $92 \mathrm{a}$ & $96 \mathrm{a}$ & $93 \mathrm{a}$ & $60 \mathrm{c}$ & $63 \mathrm{c}$ & $70 \mathrm{c}$ & $77 \mathrm{c}$ \\
$\mathrm{CV}(\%)$ & 4,2 & 6,1 & 8,2 & 5,0 & 3,7 & 3,2 & 3,6 \\
\hline
\end{tabular}

Na coluna, médias seguidas da mesma letra não diferem entre si pelo teste de Tukey a $5 \%$.

Tabela 37. Viabilidade (\%): germinação (G), tetrazólio (TZ) e emergência de plântula (EP) e vigor (\%): envelhecimento acelerado (EA), deterioração controlada (DC) e emergência de plântula (EP), de três lotes de sementes de tomate, cv. Acclaim, na primeira avaliação.

\begin{tabular}{|c|c|c|c|c|c|c|c|}
\hline \multicolumn{4}{|c|}{ Viabilidade } & \multicolumn{4}{|c|}{ Vigor } \\
\hline Lote & TG & $\mathrm{TZ}$ & EP & $\begin{array}{c}\text { EA } \\
\% \%\end{array}$ & DC & EP & TZ \\
\hline 4 & $91 \mathrm{a}$ & 98 a & $94 \mathrm{a}$ & $79 a$ & $80 a$ & $82 \mathrm{a}$ & $87 a$ \\
\hline 5 & $91 \mathrm{a}$ & $100 \mathrm{a}$ & $95 a$ & $77 a$ & $84 a$ & $83 a$ & $90 \mathrm{a}$ \\
\hline 6 & $73 \mathrm{~b}$ & $84 \mathrm{~b}$ & $85 \mathrm{~b}$ & $58 \mathrm{~b}$ & $64 \mathrm{~b}$ & $70 \mathrm{~b}$ & $78 \mathrm{~b}$ \\
\hline$C V(\%)$ & 2,8 & 6,6 & 5,6 & 3,1 & 4,8 & 5,8 & 2,7 \\
\hline
\end{tabular}

Na coluna, médias seguidas da mesma letra não diferem entre si pelo teste de Tukey a $5 \%$. 
Tabela 38. Viabilidade (\%): germinação (G), tetrazólio (TZ) e emergência de plântula (EP) e vigor (\%): envelhecimento acelerado (EA), deterioração controlada (DC) e emergência de plântula (EP), de três lotes de sementes de tomate, cv. Acclaim, na segunda avaliação.

\begin{tabular}{|c|c|c|c|c|c|c|c|}
\hline \multicolumn{4}{|c|}{ Viabilidade } & \multicolumn{4}{|c|}{ Vigor } \\
\hline Lote & TG & $\mathrm{TZ}$ & EP & EA & $\mathrm{DC}$ & EP & $\mathrm{TZ}$ \\
\hline 4 & $91 \mathrm{a}$ & $95 a b$ & $95 \mathrm{a}$ & $77 \mathrm{a}$ & $84 a$ & $82 \mathrm{a}$ & $88 \mathrm{a}$ \\
\hline 5 & $93 a$ & $98 a$ & $96 a$ & $77 a$ & $84 a$ & $81 \mathrm{a}$ & $89 a$ \\
\hline 6 & $76 \mathrm{~b}$ & $81 \mathrm{~b}$ & $84 \mathrm{~b}$ & $58 \mathrm{~b}$ & $62 \mathrm{~b}$ & $72 \mathrm{~b}$ & $77 \mathrm{~b}$ \\
\hline $\mathrm{CV}(\%)$ & 3,8 & 9,9 & 5,4 & 3,2 & 2,7 & 3,8 & 4,3 \\
\hline
\end{tabular}

Na coluna, médias seguidas da mesma letra não diferem entre si pelo teste de Tukey a $5 \%$.

Tabela 39. Viabilidade (\%): germinação (G), tetrazólio (TZ) e emergência de plântula (EP) e vigor (\%): envelhecimento acelerado (EA), deterioração controlada (DC) e emergência de plântula (EP), de três lotes de sementes de tomate, cv. Acclaim, na terceira avaliação.

\begin{tabular}{|c|c|c|c|c|c|c|c|}
\hline \multicolumn{4}{|c|}{ Viabilidade } & \multicolumn{4}{|c|}{ Vigor } \\
\hline Lote & TG & $\mathrm{TZ}$ & EP & $\begin{array}{r}\text { EA } \\
\ldots \%\end{array}$ & DC & EP & TZ \\
\hline 4 & $92 \mathrm{a}$ & $98 a$ & $92 \mathrm{a}$ & $78 a$ & $80 a$ & $83 a$ & $86 a$ \\
\hline 5 & $94 \mathrm{a}$ & $99 a$ & $91 \mathrm{a}$ & $78 a$ & $83 a$ & $83 a$ & $88 a$ \\
\hline 6 & $74 \mathrm{~b}$ & $80 \mathrm{~b}$ & $78 \mathrm{~b}$ & $59 \mathrm{~b}$ & $65 \mathrm{~b}$ & $70 \mathrm{~b}$ & $75 \mathrm{~b}$ \\
\hline$C V(\%)$ & 4,1 & 6,9 & 5,8 & 3,8 & 5,5 & 5,0 & 3,3 \\
\hline
\end{tabular}

Na coluna, médias seguidas da mesma letra não diferem entre si pelo teste de Tukey a $5 \%$. 


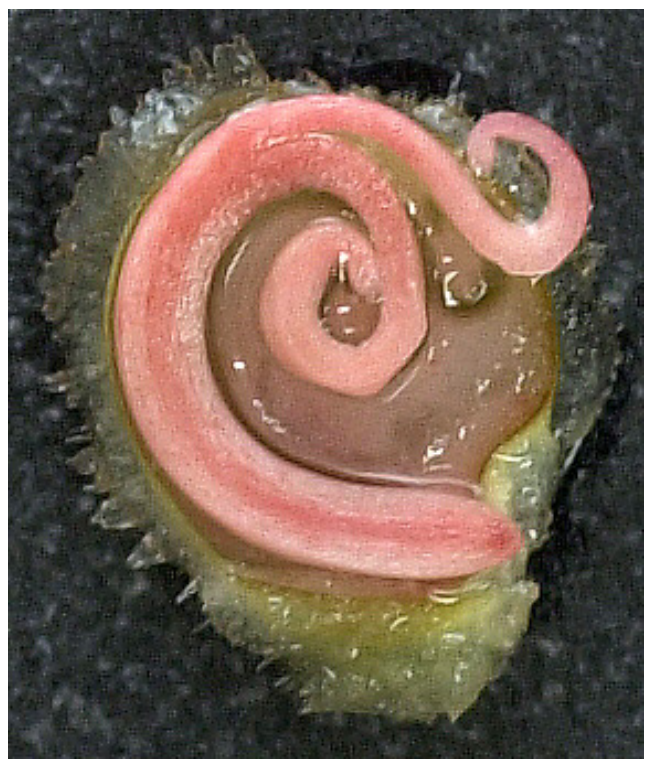

Figura 9 - Semente de tomate viável vigorosa, cv. Débora Max, hidratada por 3 horas a $45^{\circ} \mathrm{C}$ e mantida em solução de $\mathrm{TZ} 0,075 \%$, a $40^{\circ} \mathrm{C}$, por 3 horas.

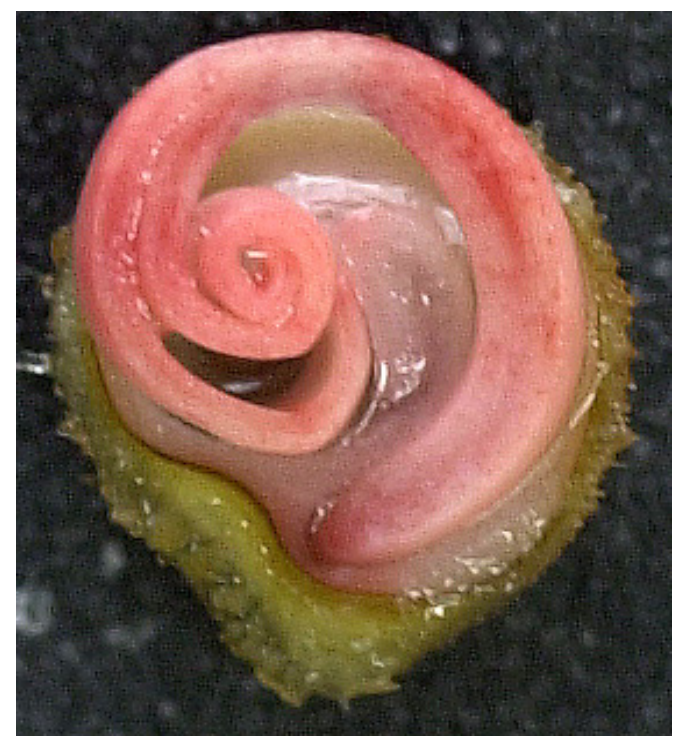

Figura 10 - Semente de tomate viável vigorosa, cv. Acclaim, hidratada por 3 horas a $45^{\circ} \mathrm{C}$ e mantida em solução de $\mathrm{TZ} 0,075 \%$, a $40^{\circ} \mathrm{C}$, por 3 horas. 


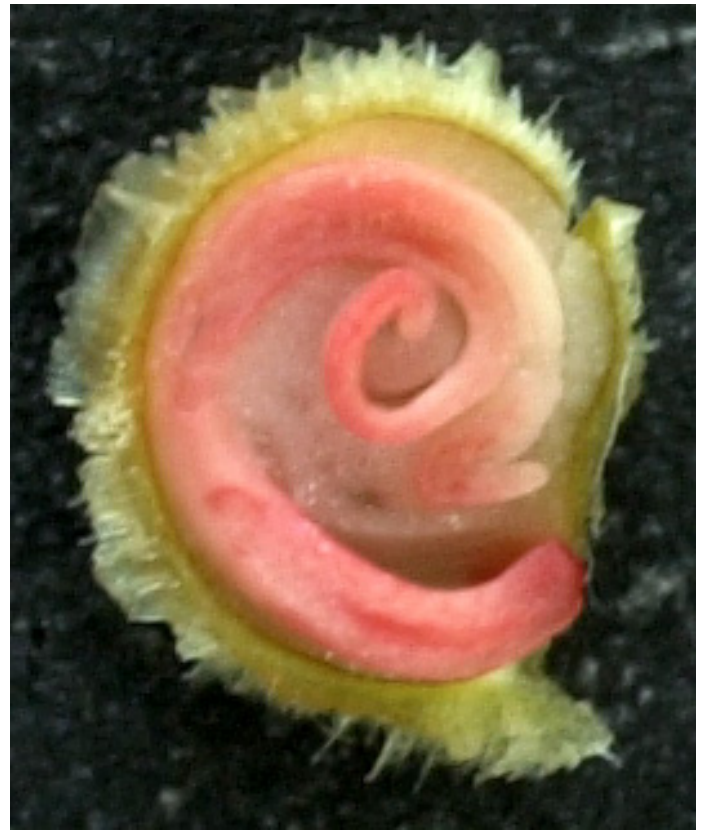

Figura 9-A - Semente de tomate viável não vigorosa, cv. Débora Max, hidratada por 3 horas a $45^{\circ} \mathrm{C}$ e mantida em solução de $\mathrm{TZ} 0,075 \%$, a $40^{\circ} \mathrm{C}$, por 3 horas.

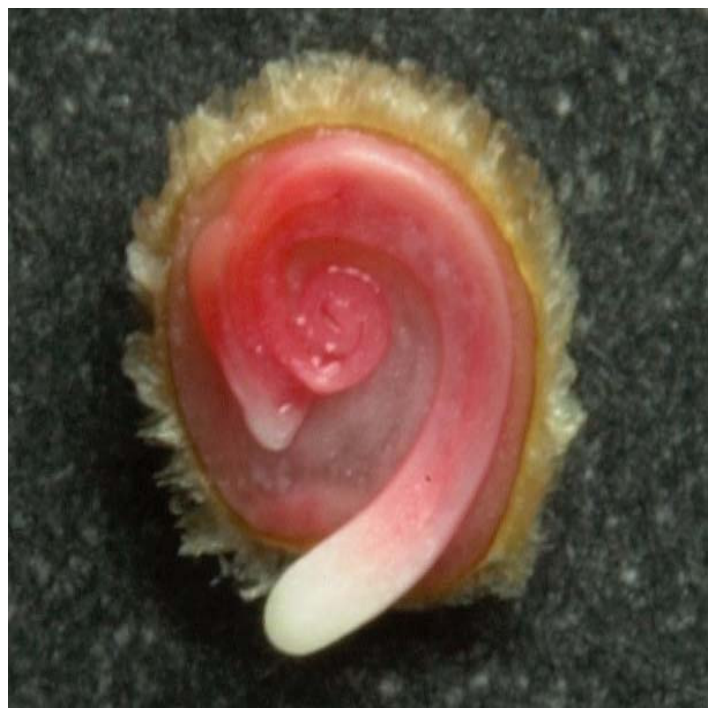

Figura 10-A - Semente de tomate viável não vigorosa, cv. Acclaim, hidratada por 3 horas a $45^{\circ} \mathrm{C}$ e mantida em solução de $\mathrm{TZ} 0,075 \%$, a $40^{\circ} \mathrm{C}$, por 3 horas. 


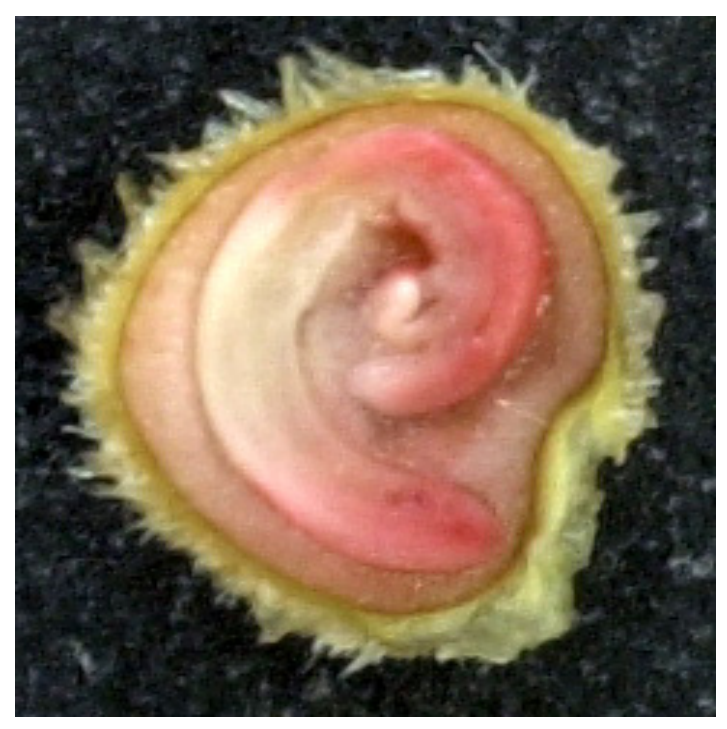

Figura 9-B - Semente de tomate não viável, cv. Débora Max, hidratada por 3 horas a $45^{\circ} \mathrm{C}$ e mantida em solução de $\mathrm{TZ} 0,075 \%$, a $40^{\circ} \mathrm{C}$, por 3 horas.

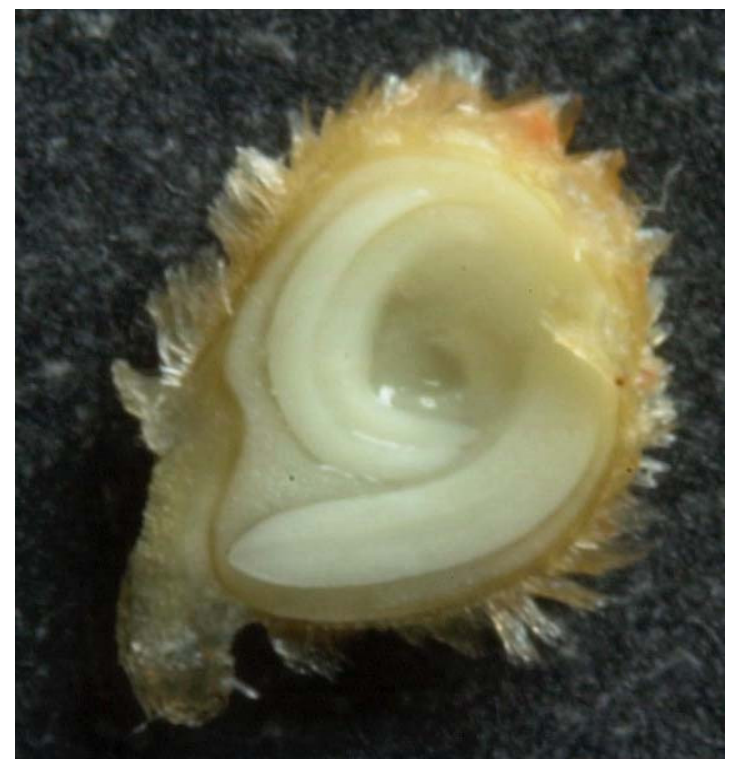

Figura 10-B - Semente de tomate não viável, cv. Acclaim, hidratada por 3 horas a $45^{\circ} \mathrm{C}$ e mantida em solução de $\mathrm{TZ} 0,075 \%$, a $40^{\circ} \mathrm{C}$, por 3 horas. 


\section{CONCLUSÕES}

O teste de tetrazólio é eficiente para estimar a viabilidade e o vigor de sementes de tomate; há a possibilidade de reduzir o período de tempo para a realização desse teste. 


\section{REFERÊNCIAS BIBLIOGRÁFICAS}

ANDRADE, R.N.B. de; SANTOS, D.S.B.; SANTOS FILHO, B.G.; MELLO, V.D.C. Testes de germinação e de tetrazólio em sementes de cenoura armazenadas por diferentes períodos. Revista Brasileira de Sementes, v.18, n.1, p.108-116, 1996.

BHÉRING, M.C.; SILVA, R.F. da; ALVARENGA, E.M.; Dias, D.C.F.S. Metodologia do teste de tetrazólio em sementes de feijão. In: KRZYZANOWSKI, F.C.; VIEIRA, R.D.; FRANÇA NETO, J.B. Vigor de sementes: conceitos e testes. Londrina PR: abrates, 1999. p.8.3.

BITTENCOURT, S.R.M. Uso do teste de tetrazólio em substituição ao de germinação na avaliação dos resultados do teste de envelhecimento acelerado em sementes de milho. Jaboticabal, 1999. 146p. Tese (Doutorado)- Faculdade de Ciências Agrárias e Veterinárias, Universidade Estadual Paulista "Júlio de Mesquita Filho".

BITTENCOURT, S.R.M.; VIEIRA, R.D. Metodologia do teste de tetrazólio em sementes de amendoim. In: KRZYZANOWSKI, F.C.; VIEIRA, R.D.; FRANÇA NETO, J.B. Vigor de sementes: conceitos e testes. Londrina, PR: abrates, 1999. p.8.2. 
BRASIL. Ministério da Agricultura, do Abastecimento e da Reforma Agrária Secretaria Nacional de Defesa Agropecuária. Regras para Análise de Sementes. Brasília, DF.; 1992, 365p.

COSTA, N.P. da,. Metodologia alternativa para o teste de tetrazólio em sementes de soja. Piracicaba, 1992. 132p. Tese (Doutorado) - Escola Superior de Agricultura "Luiz de Queiroz" - ESALQ/ USP.

COSTA, N.P. da; MARCOS FILHO, J. Altenative methodology for the tetrazolium test for soybean seed. Seed Science and Technology, v.22, n.1, p.9-17. 1994.

COSTA, N.P. da; FRANÇA NETO, J.B.; KRZYZANOWSKI, F.C.; HENNING, A.A.; PEREIRA, J.E. Avaliação de metodologia alternativa para o teste de tetrazólio para sementes de soja. Scientia Agricola, v.55, n.2, p.305-312, maio/ago., 1998.

DELOUCHE, J. C.; STILL, T. W.; RASPET, M. ; LIENHARD, M. O teste de tetrazólio para viabilidade da semente. Brasília: AGIPLAN, 1976. 103p.

DIAS, D.C.F.S.; BARROS, D.I.; BHÉRING, M.C.; ARAÚJO, E.F.; DIAS, L.A.S. Teste de tetrazólio em sementes de abóbora. Informativo Abrates, v.11, n.2, p.124, 2001.

DIAS, M.C.L.L.; BARROS, A.S.R. Metodologia do teste de tetrazólio em sementes de milho. In: KRZYZANOWSKI, F.C.; VIEIRA, R.D.; FRANÇA NETO, J.B. Vigor de sementes: conceitos e testes. Londrina, PR.: abrates, 1999. p.8.4. 
FNP CONSULTORIA \& COMÉRCIO. Agrianual 2002: anuário de agricultura brasileira. São Paulo, 2001, 520p.

FRANÇA NETO, J.B.; KRZYZANOWSKI, F.C.; COSTA, N.P. da,. Metodologia do teste de tetrazólio em sementes de soja. In: KRZYZANOWSKI, F.C.; VIEIRA, R.D.; FRANÇA NETO, J.B. Vigor de sementes: conceitos e testes. Londrina-PR: abrates, 1999. p.8.5.

GRABE, D.F. Manual do teste de tetrazólio em sementes. Brasília: AGIPLAN, 1976, 85p.

LANKON, G. The topographical tetrazolium method for determining the germinating capacity of seeds. Plant Physiology, v.24, n.3, p.389-394, 1949.

MARCOS FILHO, J.; CÍCERO, S.M.; SILVA, W.R. da,. Avaliação da qualidade das sementes. FEALQ, 1987, 230p.

MOORE, R.P. Tetrazolium testing handbook. S.L. S. ed, 1977. 1 v.

NASCIMENTO, W.M. Mercado de sementes de hortaliças no Brasil. Horticultura Brasileira, v.19, n.2, p.183, jul. 2001.

NASCIMENTO, W.M.; BARROS, B.C.G. de; PESSOA, H.B.D.V. Teste de envelhecimento acelerado em sementes de tomate. Revista Brasileira de Sementes, v.15, n.2, p.251-253, 1993.

NOVEMBRE, A.D.L.C., DIAS, D.C.F.S., CHAMA, H.M.C.P., MARCOS FILHO,J. Estudo da metodologia dos testes de envelhecimento acelerado e de condutividade elétrica para sementes de tomate. Informativo Abrates, v.3, n.3, p.140, 1995. 
PANOBIANCO, M. Avaliação do potencial fisiológico da sementes de tomate. Piracicaba, 2000. 152p. Tese (Doutorado) - Escola Superior de Agricultura "Luiz de Queiroz", Universidade de São Paulo.

RODO, A.B. Testes de vigor em sementes de tomate Lycopersicon lycopersicum (L) Karsten com ênfase ao teste de condutividade elétrica. Pelotas, 1997. 41p. Dissertação (Mestrado)- Universidade Federal de Pelotas.

RODO, A.B. Avaliação do potencial de sementes de cebola e sua relação com o desempenho das plantas em campo. Piracicaba, 2002. 123p. Tese (Doutorado) - Escola Superior de Agricultura "Luiz de Queiroz", Universidade de São Paulo.

ROSSETTO, C.A.V. Estudos sobre a absorção de água e o desempenho de sementes de soja. Piracicaba, 1995. 144p. Tese (Doutorado) - Escola Superior de Agricultura “Luiz de Queiroz”, Universidade de São Paulo.

SÁ, M.E. de,. Condutividade elétrica em sementes de tomate (Lycopersicon lycopersicum L.). Scientia Agricola, v.56,n.1, p.13-19, jan/mar, 1999.

VIEIRA, M.G.G.C.; GUIMARÃES, R.M.; VON PINHO, E.V.R.; GUIMARÃES, R.J; OLIVEIRA, J.A. Testes rápidos para a determinação da viabilidade e da incidência de danos mecânicos em sementes de cafeeiro. Boletim Agropecuário, n.26, p.5-25,1998.

VIEIRA, M.G.G.C.; VON PINHO, E.V.R. Metodologia do teste de tetrazólio em sementes de algodão. In: KRZYZANOWSKI, F.C.; VIEIRA, R.D.; FRANÇA NETO, J.B. Vigor em sementes: conceitos e testes. Londrina-PR: abrates, 1999. p.8. 
ZONTA, E.P.; MACHADO, A.A. Sistema de análise estatística para microcomputadores-SANEST. Pelotas, 1984, 109p. 